\title{
Water balance and hydrology research in a mountainous permafrost watershed in upland streams of the Kolyma River, Russia: a database from the Kolyma Water-Balance Station, 1948-1997
}

\author{
Olga Makarieva ${ }^{1,2,3,4}$, Nataliia Nesterova ${ }^{3,4}$, Lyudmila Lebedeva ${ }^{2}$, and Sergey Sushansky ${ }^{5, *}$ \\ ${ }^{1}$ Gidrotehproekt Ltd, St. Petersburg, 199178, Russia \\ ${ }^{2}$ Melnikov Permafrost Institute, Merzlotnaya st., 36, Yakutsk 677010, Russia \\ ${ }^{3}$ Saint Petersburg State University, Institute of Earth Sciences, \\ 7/9 Universitetskaya nab, St. Petersburg, 199034, Russia \\ ${ }^{4}$ State Hydrological Institute, Department of Experimental Hydrology and Mathematical Modelling \\ of Hydrological Processes, 23 2-ya liniya VO, St. Petersburg, 199053, Russia \\ ${ }^{5}$ Kolyma Department of Russian Federal Service for Hydrometeorology and \\ Environmental Monitoring, 7/13 Parkovaya st., Magadan, 685000, Russia \\ *retired \\ Correspondence: Olga Makarieva (omakarieva@gmail.com)
}

Received: 12 November 2017 - Discussion started: 17 November 2017

Revised: 21 February 2018 - Accepted: 8 March 2018 - Published: 4 April 2018

\begin{abstract}
In 2018, 70 years have passed since the beginning of observations at the Kolyma Water-Balance Station (KWBS), a unique scientific research hydrological and permafrost catchment. The volume and duration (50 continuous years) of hydrometeorological standard and experimental data, characterizing the natural conditions and processes occurring in mountainous permafrost conditions, significantly exceed any counterparts elsewhere in the world. The data are representative of mountainous territory of the North-East of Russia. In 1997, the station was terminated, thereby leaving Russia without operating research watersheds in the permafrost zone. This paper describes the dataset containing the series of daily runoff from 10 watersheds with an area from 0.27 to $21.3 \mathrm{~km}^{2}$, precipitation, meteorological observations, evaporation from soil and snow, snow surveys, soil thaw and freeze depths, and soil temperature for the period 1948-1997. It also highlights the main historical stages of the station's existence, its work and scientific significance, and outlines the prospects for its future, where the Kolyma Water-Balance Station could be restored to the status of a scientific research watershed and become a valuable international centre for hydrological research in permafrost. The data are available at https://doi.org/10.1594/PANGAEA.881731.
\end{abstract}

\section{Introduction}

In 2018 we celebrate 70 years since observations at the Kolyma Water-Balance Station (KWBS) began. This hydrological and permafrost research catchment has accumulated standard and experimental data unique in terms of both their amount and duration.
Laudon et al. (2017) recognize the KWBS as a currently functioning scientific station, even though scientific research was suspended here 20 years ago, and nowadays only standard observations at the meteorological site and one runoff gauge are carried out.

Eurasia contributes $75 \%$ of the total terrestrial runoff to the Arctic Ocean and three of the four major Arctic rivers are located in Siberia (Shiklomanov et al., 2002). Peterson 
et al. (2002) suggested that the net discharge from the six largest Eurasian rivers flowing into the Arctic Ocean (Severnaya Dvina, Pechora, Ob', Yenisey, Lena, and Kolyma) increased by $7 \%$ during the 20th century. As also mentioned by Laudon et al. (2017), the number of scientific and hydrological research stations in the northern regions of the world has decreased by $40 \%$, and it happened alongside the most significant climate change in the Arctic in recorded history.

The KWBS is located in the headwaters of the Kolyma River $\left(61.85^{\circ} \mathrm{N}, 147.67^{\circ} \mathrm{E}\right)$, in a mountainous cryolithozone (Figs. 1 and 2).

The network of measurement sites and watersheds set up in the former USSR were referred to as water balance stations. The overall goals of this network were detailed monitoring, analysis and study of water balance and hydrologic regimes on slopes and small catchments in different environmental settings for the development of improved methods for hydrological forecasts and for flow characteristic assessment to support engineering design. The KWBS was 1 of 26 water balance stations of the USSR, and the only one located in the zone of continuous permafrost.

During the period 1948 to 1997 , the KWBS accumulated a huge amount of data on hydro-meteorological and special observations of a unique duration (40-50 years). At the KWBS there were 10 hydrological gauges at catchments ranging between 0.27 and $21.3 \mathrm{~km}^{2}$, two meteorological plots, 55 (in total) precipitation gauges, over 30 frost tubes (cryopedometers), several groundwater wells, and evaporation, water balance and runoff plots. In addition, regular snow surveys were conducted, as well as experimental investigations of specific hydrological and permafrost processes.

After 1997, special water balance and research observations at the KWBS were ceased. One weather station and five runoff gauges functioned at the KWBS up to midJune 2013, when an extreme flash flood destroyed four level gauges. Nowadays only standard observations are conducted at the Nizhnyaya meteorological site and at the Kontaktovy (Nizhny) runoff gauge.

The data were published in 40 reports, the first one covering the period 1948-1957. Following issues were published annually (KWBS Observation Reports, 1959-1997).

Though in the last several decades and more recently, many research watersheds were established in the Arctic zone of the USA and Canada, to the best of our knowledge, the first systematic cold-region hydrology observations in North America began not earlier than the 1960s. For example, the Caribou-Poker Creeks Research Watershed was established only in 1969 (Hinzman et al., 2002), 20 years later than the KWBS.

One may mention numerous scientific catchments in Alaska - Fish Creek (Pacific Northwest Natural Areas Network, 2014), Toolik station (Hoobbie et al., 2003), Tanana River (Yarie et al., 1998), Kuparuk River (Arp and Stuefer, 2017, Kane and Hinzman, 2009), Imnavait River (Walker and Walker, 1996), Putuligayuk River (Kane and Hinz- man, 2009), as well as Arctic monitoring programmes NPRHydrology (NPR-A Hydrology, 2018) and the Arctic Observatory Network (Arctic Observatory Network, 2018).

The studies at research watersheds of Canada are integrated into scientific programmes and accompanied by data analysis and model development and applications. For example, the Changing Cold Regions Network project (Changing Cold Regions Network, 2018) includes field studies on 14 watersheds and the use of two Canadian models - CRHM and CLASS. The Improving Processes and Parameterization for Prediction in Cold Regions Hydrology (IP3) project (Improving Processes and Parameterization for Prediction in Cold Regions Hydrology, 2018) combined 10 research watersheds and four hydrological models - CRHM (Pomeroy et al., 2007), CLASS (Verseghy, 1991), MESH (Pietroniro et al., 2007), and GEM (Yeh et al., 2002).

Although there are large mountainous areas in other cold regions of the world, the combination of an extremely severe climate (mean annual air temperature reaches $-11.3^{\circ} \mathrm{C}$ ) and continuous permafrost creates unique conditions at the KWBS which are not presented at any other research watershed.

Nasybulin (1976) showed that the hydrological regime at the KWBS is representative of the whole Upper Kolyma Plateau. Taking into account the similarity of the main landscape types across mountainous regions of North-Eastern Russia to those found at the KWBS, the conclusion can be made that hydrological conditions at the KWBS are actually representative of an even vaster ungauged area than described by Nasybulin (1976).

Sufficiently long time series of observations which were continuously conducted by uniform methods and covered the pre-warming period are of high importance for the studies of climate change impact on hydrology in the Arctic.

KWBS observation results were reflected in many publications dedicated to different aspects of runoff formation in the continuous permafrost region, active layer dynamics, underlying surface structure and its influence on hydrological processes. Based on the KWBS data, the following studies were carried out:

- water balance formation (Kuznetsov et al., 1969; Boyarintsev, 1980; Boyarintsev and Gopchenko, 1992; Suchansky, 2002; Zhuravin, 2004; Lebedeva et al., 2017),

- peak and spring flood runoff in small rivers in the permafrost zone (Boyarintsev, 1988),

- base flow (Boyarintsev and Nikolaev, 1986; Glotov, 2002),

- principles of runoff cryo-regulation (Alexeev et al., 2011),

- ice content dynamics of rocky talus deposits (Bantsekina, 2001), 
(a)

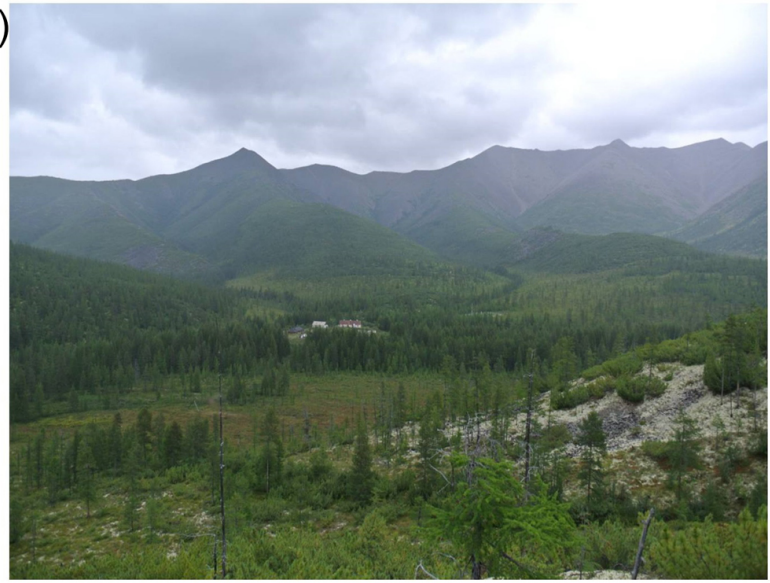

(b)

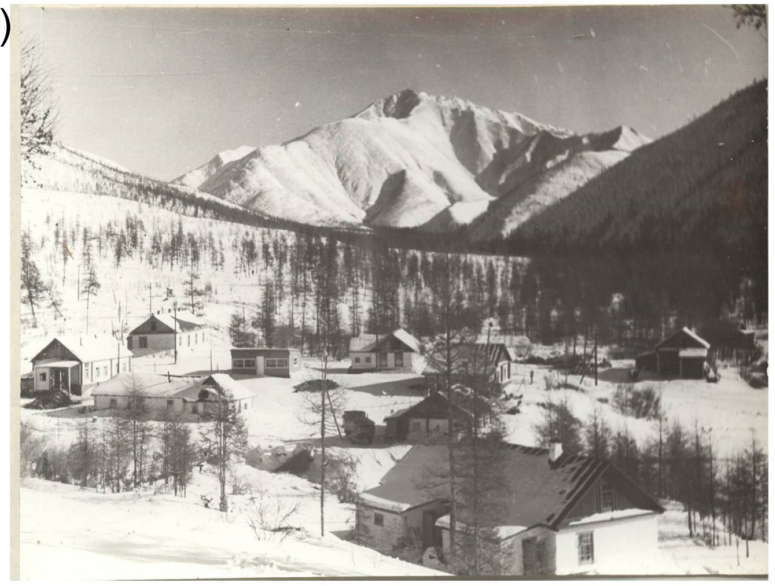

Figure 1. View of the Kolyma Water-Balance Station in (a) August 2016 (photo by O. Makarieva), and (b) historical photo from Sushansky (1989).

- processes of intra-ground condensation (Reinyuk, 1959; Boyarintsev et al., 1991; Bantsekina and Mikhailov, 2009), and

- floodplain taliks in continuous permafrost (Mikhaylov, 2013), and many others.

Collected data were also used for development and testing of different geoscience models of

- runoff formation (Kuchment et al., 2000; Gusev et al., 2006; Semenova et al., 2013; Lebedeva et al., 2015; Vinogradov et al., 2015),

- climatic aspects (Shmakin, 1998), and

- land surface and vegetation dynamics (Tikhmenev, 2008).

In this paper, we present a hydrometeorological and permafrost-related dataset for 50 continuous years from 1948 to 1997 for the KWBS, the Kontaktovy creek watershed, which is representative of vast mountainous territories of the continuous permafrost zone of Eastern Siberia and the northeast of Russia. This dataset is unique in terms of its volume and duration of hydrometeorological standard and experimental data. It may be used in many research tasks, but is of particular importance in studying runoff formation processes and model development in permafrost regions.

\section{Site description}

The Kolyma Water-Balance Station is located in the Tenkinsky district of the Magadan region of Russia within the Upper Kolyma highland. The station's territory - the Kontaktovy creek catchment with area $21.3 \mathrm{~km}^{2}$ - is a part of the Pravy Itrikan River which flows into the Kulu River basin, which is the right tributary of the Kolyma River. The station is located $16 \mathrm{~km}$ from the Kulu village settlement. It is characterized by a mountain landscape typical of the upper reaches of the Kolyma River. The territory of the basin is severely cut up with creek valleys. These valleys are narrow, with steep slopes, and watershed lines are mostly well delineated. Absolute elevations of the basin range between $823 \mathrm{~m}$ a.s.l. near the Kontaktovy creek outlet and $1700 \mathrm{~m}$ a.s.l. at watershed divides. The length of the creek is $8.9 \mathrm{~km}$. The catchment is extended in the latitudinal direction and has an asymmetric shape. The slopes of the catchment area have mainly southern exposure (53\% of the slope area), the slopes of the northern and eastern exposure have a $24 \%$ share, and the western one $23 \%$. The density of the river network in the basin is $2.5 \mathrm{~km}$ per square kilometre. The main river canal is meandering. The steepness of the slopes ranges from 200 to $800 \%$ (Fig. 1).

The station is located in the continuous permafrost zone. Permafrost thickness varies from 120 to $210 \mathrm{~m}$ in valleys and can reach $300-400 \mathrm{~m}$ in highlands, following the relief. Seasonal soil thaw depth depends on slope exposition, altitude and landscape and changes from $0.2-0.8 \mathrm{~m}$ on north-facing slopes to $1.5-3.0 \mathrm{~m}$ on south-facing ones.

The KWBS is situated in the transitional zone between forest-tundra and coniferous taiga. Soil types vary from stony-rock debris to clayey podzol with partially decayed organic material underlain by frozen soil and bedrock. Most of the KWBS area is covered by rocky talus, practically without vegetation (34\%). Dwarf cedar and alder shrubs are common on south-facing slopes and cover about $27 \%$ of the territory. Larch sparse woodland with moss-lichen cover is typical of steep north-facing slopes $(12 \%)$. Open terrain larch wood $(15 \%)$ and swampy sparse growth forest with minimal permafrost thaw depth, constant excessive stagnant moisturizing, and tussock or knobby microrelief $(12 \%)$ character- 
(a)

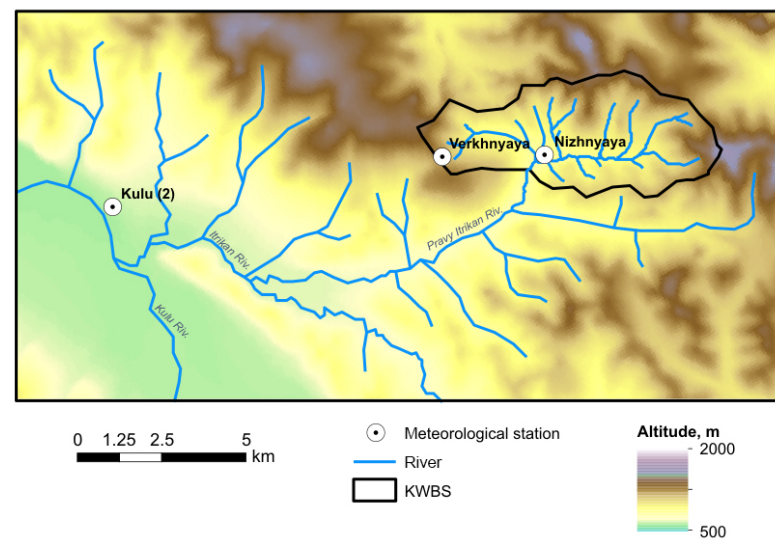

(b)

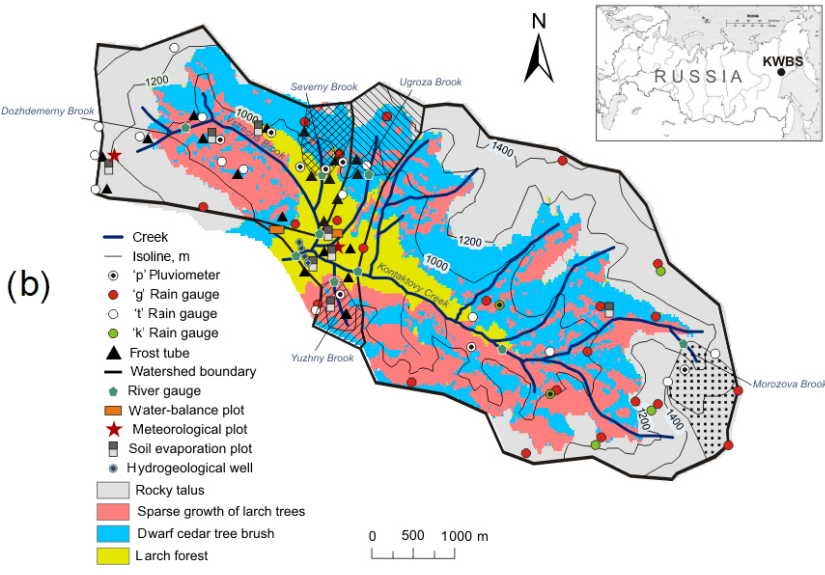

Figure 2. Scheme of the KWBS indicating the location of observation sites.

ize creek valleys. The estimates of landscape distribution are given here following Korolev (1984) (Fig. 2b).

Along the whole length of the Kontaktovy creek, channel taliks can be found. They go all the way through the layer of alluvial sediments and their depth may reach $15 \mathrm{~m}$ in the cross section of the Nizhny hydrological gauge (Mikhaylov, 2013) and $5 \mathrm{~m}$ on the floodplain (Glotov, 2002). In summer, the talik forms a single hydraulic system with waters of the active layer and the creek channel. In winter it freezes only partially. In the talik located below the Kontaktovy-Nizhny gauge, flow exists till the beginning of snowmelt, which is evidenced by a continuous drop in levels in hydrogeological wells (Glotov, 2002).

\subsection{History of the KWBS}

The KWBS was established on 15 October 1947 and was initially known as the Itrikanskaya runoff station of the Dalstroy (Far North Construction Trust organized in 1931) Hydrometeorological Service. In 1948-1956 and 1957-1969 it was called the Kulinskaya and Kolyma runoff station respectively. The primary goal of this station was to study runoff formation processes in small river catchments in mountain permafrost landscapes, typical for the North-Eastern USSR.

In May 1948, the first runoff observations at the Kontaktovy creek and Vstrecha brook were launched, as well as regular observations at the Nizhnyaya weather station ( 850 ma.s.l.). A few months later, on 1 September 1948, observations at the Verkhnyaya weather station (1220 m a.s.1.) were started. In 1948, stage gauges Sredny, Nizhny and Vstrecha were equipped with automatic water level recorders, gauging footbridges and flumes.

During the period 1949-1957, at the Vstrecha brook catchment, a rain-gauge network was organized. Runoff gauges at the Severny, Dozhdemerny, and Vstrecha brooks were equipped with various hydrometric facilities. Observations of soil, water and snow evaporation, soil freezing and thawing commenced, as well as experimental observations at a runoff plot.

At the end of the 1940s and early 1950s, technical staff of the station were mainly former convicts. During the first few years, the workers of the station built houses for themselves, collected firewood and organized the household. The winter of 1955-1956 appeared to be especially severe for the staff, since due to the deep snow cover it was difficult to move around the territory of the KWBS, there was no transport connection with the Tenkinskaya highway, and delivery of firewood, needed for heating houses and service buildings, was also difficult. When it was impossible to get to the highway by car, bread and mail were delivered from the Kulu village settlement utilizing horses once every 7-10 days.

The 20 to 25 staff members were accommodated in three small huts, hardly suitable for living. That winter they mainly had to collect and prepare firewood in the afternoon; in the morning everybody had to go (despite their rank or position) in deep snow and at $-50{ }^{\circ} \mathrm{C}$ to the nearest small river valley looking for firewood, and then they pulled it back home, where they fired furnaces. Only by the time it got dark did it became warm enough to stay in the workroom and could they start observation data processing.

The working day lasted until 22:00 or 23:00. Since there was no electricity, they used kerosene lamps filled with a mixture of petrol and salt. In summer 1956 there were only 13 people left at the station: some of them were taken to help with haymaking to prepare hay for their subsidiary holding that consisted of two cows and a horse (as recollected by the chief of the station V.G. Osipov and the hydrologisttechnician A.I. Ipatieva, informational letter, 1988).

In 1957 the station was handed over to the jurisdiction of the Kolyma hydro-meteorological service administration, and in 1958 the electrification of the station started. At that time there were active steps taken toward fitting out the station with new types of devices and equipment, engaging new specialists in hydro-meteorology, and building accommodation facilities.

In 1960 runoff observations at the Yuzhny brook began. The optimization of the precipitation network was continued, 
Table 1. List of meteorological observation data. $\mathrm{n} / \mathrm{a}$ - not applicable.

\begin{tabular}{|c|c|c|c|c|}
\hline Station & Nizhnyaya & Verkhnyaya & Kulu & Kulu2 \\
\hline Latitude & 61.85 & 61.86 & 61.88 & 61.88 \\
\hline Longitude & 147.67 & 147.61 & 147.43 & 147.44 \\
\hline Elevation, $\mathrm{m}$ & 850 & 1220 & 670 & 635 \\
\hline Air temperature & \multirow{2}{*}{$1948-1997$} & \multirow{2}{*}{$1948-1972$} & \multirow{3}{*}{\multicolumn{2}{|c|}{$\begin{array}{l}1981-1991 \\
1992-1997\end{array}$}} \\
\hline Water vapour pressure & & & & \\
\hline Vapour pressure deficit & 1974-1997 & $\mathrm{n} / \mathrm{a}$ & & \\
\hline Atmospheric pressure & $1951-1997$ & 1951-1972 & & \\
\hline Low cloud amount & \multirow{4}{*}{ 1948-1997 } & \multirow{4}{*}{$1948-1972$} & & \\
\hline Total cloud amount & & & & \\
\hline Wind speed & & & & \\
\hline Surface temperature & & & & \\
\hline
\end{tabular}

meaning the establishment of rain gauges in new locations and shutting down some non-representative rain gauges. Radio rain gauges were also installed.

In 1963 two new water balance sites (nos. 2 and 3) were organized.

In 1968 runoff measurements were started at the unique research object, at the Morozova brook catchment, which has no vegetation cover and is composed of rocky talus.

In 1969 the Kolyma runoff station was renamed the KWBS. In these years there was a transition to broad experimental water balance observations of all elements and to an enhanced technical level of research.

From 1970, the KWBS carried out snowpack observations at avalanche sites of the Tenkinskaya road, as well as stratigraphy, temperature and physical and mechanical properties of snow at four sites. From 1980 additional observations of the dynamics of icing formation at the Kontaktovy creek were introduced. In 1982 observations of soil moisture were started at three agro-hydrological sites at the fields of the "Kulu" state farm.

In 1976 the station hosted a delegation of USA scientists. They highly praised the professional and personal qualities of the station's staff members and their commitment, on which extensive field studies and theoretical works were based, despite the equipment being rather simple and living conditions extreme. According to Slaughter and Bilello (1977), the data recorded at the KWBS were unique and unprecedented for world practice.

Since the beginning of the 1990s, the research programme at the station has been gradually cutting back. After 1997, water balance observations at the KWBS were ceased. One weather station and five runoff gauges functioned at the KWBS up to the middle of June 2013, when an extreme flash flood destroyed four level gauges. Nowadays only standard observations are conducted at the Nizhnyaya meteorological site and at the Kontaktovy (Nizhny) runoff gauge.

\section{Data description}

\subsection{Meteorological observations}

The observations of meteorological elements were carried out at three meteorological stations in different periods (Fig. 2a). The database includes daily values of air temperature, water vapour pressure, vapour pressure deficit, atmospheric pressure, wind speed, low and total cloud amount, and surface temperature (Table 1).

Meteorological station Verkhnyaya (1220 ma.s.1., 19481972) was located in the upper reaches of the Dozhemerny brook in the saddle between two hills. The horizon is closed by the hills from the south and north which are at $30-40 \mathrm{~m}$ distance from the site. The horizon is open from the east and west; strong winds are observed here. The surface at the station plot is hummocky, covered with grassy vegetation with no woody vegetation around it. The nearest building - the station house - was located $48 \mathrm{~m}$ away from the station plot. The depth of seasonal thaw of permafrost reaches $1.5 \mathrm{~m}$.

Meteorological station Nizhnyaya (850 ma.s.1., 19481997 ) is located on the edge of a larch forest, on the terrace watershed between the Kontaktovy creek and the Ugroza brook, which has a slight slope to the south-west. The nearest trees are located $50 \mathrm{~m}$ away, the buildings $100 \mathrm{~m}$ from the station. The site is surrounded by mountains of up to $1400 \mathrm{~m}$ a.s.1., the nearest of them at a distance of $200-500 \mathrm{~m}$. The height of the weather vane is $11.3 \mathrm{~m}$. The surface of the station plot is covered by hummocks, with moss, peat and individual bilberry and blueberry bushes. The area is sur- 
rounded by a sparse larch forest from the north, east and south. The depth of permafrost seasonal thaw reaches $1.5 \mathrm{~m}$.

Meteorological station Kulu (670 m a.s.l., 1981-1991) was located on the right slope of the broad valley of the Kulu River. The slope has a western exposure $\left(4-6^{\circ}\right)$. The height of the weather vane is $10.7 \mathrm{~m}$. The area is surrounded by larch trees of 6-8 m height from the west, north and east. The soils are loamy with the inclusion of small gravel. The underlying surface consists of berry, grass and sphagnum mosses, and sometimes bare soil. The depth of seasonal thawing of permafrost reaches $1.8-2 \mathrm{~m}$.

In September 1992, the Kulu station (635 m a.s.l., 19921997) was moved to the residential building of the KWBS in the south-eastern part of the Kulu village. Residential and technical buildings were located around the meteorological plot. There was a road to the south of the station. The soil is marshy, covered with rubble and grass. This new location of the Kulu station is marked as Kulu2 station in the database.

The list of instruments used and the accuracy of observations for each meteorological element are presented in the description files of the database.

\subsection{Precipitation}

In total, precipitation was observed at 47 gauges within the KWBS territory during different periods. Continuous daily all-year-round precipitation data are available for the period 1948-1997 for gauge no. 12 at meteorological station Nizhnyaya and for gauge no. 54 at meteorological station Kulu for 1981-1997. Four gauges have the data of daily totals during the warm season for the period for more than 30 years and another 18 gauges for different shorter periods. Usually the start of daily observations at those gauges was initiated by the beginning of the snowmelt period and lasted until the end of September. Monthly sums of precipitation were measured at 30 gauges, 10- and 5-day sums at 21 and 18 gauges respectively.

In 1948, precipitation gauge stations for measuring daily precipitation were equipped with the Nipher-shielded and Tretyakov-shielded precipitation gauges (Fig. 3a). In 19481958 the observations were carried out with both devices in parallel, and after 1959 only Tretyakov gauges were used. Tretyakov precipitation gauges were also used for measuring precipitation totals in 5- and 10-day periods.

The other types of precipitation gauges applied at the KWBS are the Kosarev and ground rain gauge (GR-28) (Fig. 3b, c).

GR-28 consists of a rain bucket of a cylinder form and height of $400 \mathrm{~mm}$, receiving area $500 \mathrm{~cm}^{2}$ and a socket for its installation several centimetres above the ground. GR-28 were usually installed on 1 June and dismantled on 1 September and used for rain measurements over the longer period, typically 1 month. Only those GR-28 which were installed at the soil evaporation plots measured precipitation every day (Kedrolivansky and Sternzat, 1953).
The Kosarev precipitation gauge is a cylindrical, tapering upward metal vessel with a reception area of $500 \mathrm{~cm}^{2}$. The lower part of the bucket ends with a cone equipped with a crane to drain accumulated precipitation. Kosarev gauges were used for monthly precipitation measurements from 1 October to 1 May.

In 1960-1963 there was an attempt to register precipitation with automatic radio-precipitation gauges, but due to improper performance of the devices those observations were stopped.

In 1988, precipitation observations at the KWBS were carried out with 36 precipitation and rain gauges, distributed relatively evenly throughout the area and altitudinal zones. Average density of the precipitation network at that time was 1.6 units per $1 \mathrm{~km}^{2}$.

For the period 1948-1968, precipitation data were published in the Observation Reports as they were (without any correction). Starting from 1969, all daily, 5-day and 10-day total data from Tretyakov rain gauges were corrected for wetting losses according to the Manual for hydrometeorological stations (1969). The correction value for precipitation events varied from 0.0 to $0.2 \mathrm{~mm}$ depending on the amount of observed precipitation and weather conditions. In the annual average, the value of wetting loss correction did not exceed $5 \%$ of the total amount of precipitation, though in some years it could reach up to 9-10\%. In 1948-1983, monthly sums data obtained from the GR-28 and Kosarev gauges were published without any correction. In 1984 wetting loss correction was introduced to GR-28 observations as well. In the database the precipitation data are presented in their original form without any changes.

The analysis of water balance, climate change impact on river runoff, or hydrological modelling requires accurate and reliable precipitation data. Arctic and mountainous regions are characterized by high bias of precipitation measurements because of the significant amount of snowfall precipitation (WMO Report no. 67, 1998). Monthly estimates of this bias often vary from 5 to $40 \%$. Biases are larger in winter than in summer largely due to the deleterious effect of the wind on snowfall (Groisman et al., 2014).

Three main methods of winter precipitation bias correction have been suggested for the Tretyakov gauge, which was the main type of precipitation gauge at the KWBS. They are the WMO methodology (Yang and Goodison et al., 1995), the Northern European countries method (Forland et al., 1996) and the approach developed by Golubev (WMO Report no. 67, 1998). The basis of all three methods for correcting measured precipitation is the dependence of the aerodynamic coefficient on wind speed, air temperature, precipitation type and wind protection.

In the described database each precipitation gauge (if it was available) has the description of its location, altitude, slope exposure, and vegetation type. An additional characteristic is the degree of protection characterized by five types of Schwer (1976) classification (Ia, Ib - protected; IIa, IIb - 
(a)

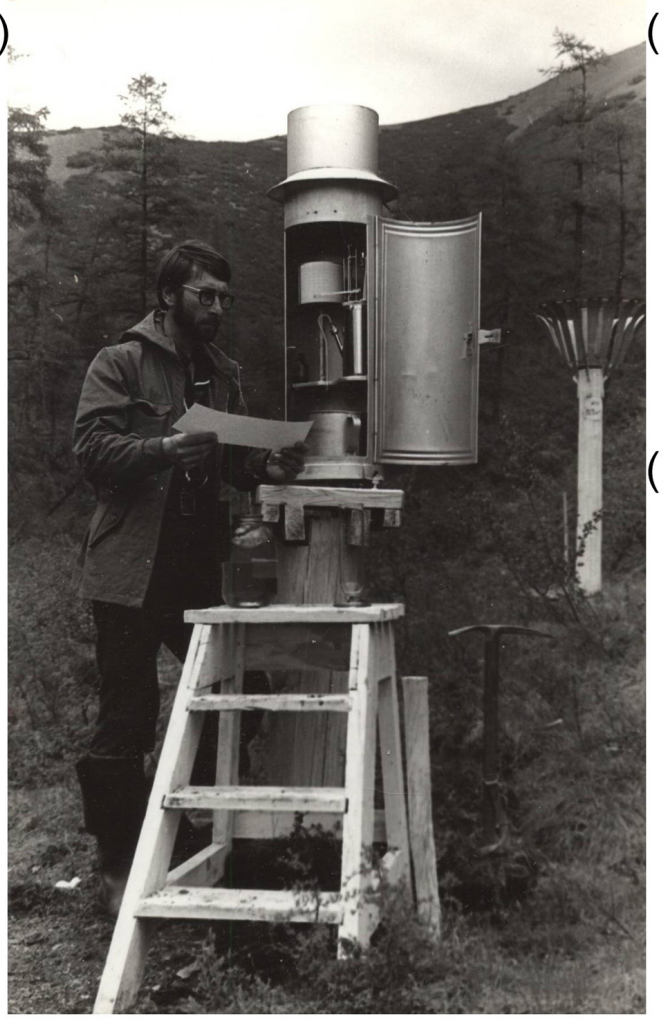

(b)

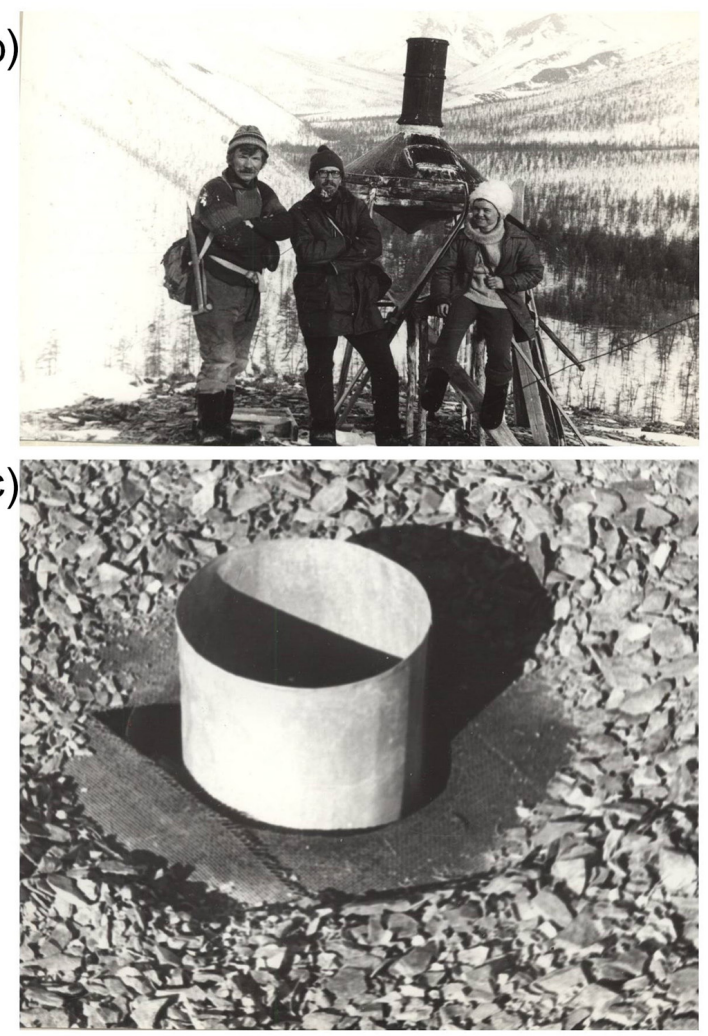

Figure 3. (a) Pluviometer, Tretyakov gauge; (b) Kosarev gauge; (c) remains of ground gauge GR-28 (Sushansky, 1988, 1989).

half-protected; III - open; IV - shore station). The database also contains the series of daily wind speed for three meteorological stations which combined with the information on location of gauges and their characteristics can be used as a proxy for introducing bias corrections.

\subsection{Snow surveys}

Snow cover observations were started in 1950 and initially conducted at two catchments, two meteorological plots and four typical squares. In 1959-1960 the number of catchments with snow surveys reached five. Up to 1971, snow surveys were conducted once per month starting in November and finishing in May at small catchments (the Severny, Yuzhny, Dogdemerny and Vstrecha) and once before spring snowmelt at Kontaktovy-Nizhny. Since 1972, the observations have been reduced to one survey per year (usually at the end of April) for all watersheds (Fig. 4). Table 2 shows the number of snow routes, their total length and number of measurement points, including their distribution among different landscapes of the catchments. Snow depth was measured every $10 \mathrm{~m}$, snow density every $100 \mathrm{~m}$ at most of the watersheds, and at 5 and $50 \mathrm{~m}$ respectively at the Morozova brook watershed.

Based on the data on measured snow height and snow weight accounting for landscape and elevation distribution, the average SWE for individual watersheds and landscapes was calculated and published in the Observation Reports.

Average depth of snow cover is presented with an accuracy of $1 \mathrm{~cm}$, density of $0.01 \mathrm{~g} \mathrm{~cm}^{-3}$ and SWE $1 \mathrm{~mm}$.

\subsection{Soil evaporation}

Three types of evaporimeters were used at the KWBS.

A Rykachev evaporimeter was used for the soil evaporation measurements in the 1950s. It consists of a sealed square rectangular box with a core sample (Fig. 5a). The box was placed inside another box installed in the ground. Since the inner box was sealed, the device did not allow for water infiltration (Chebotarev, 1939).

A Gorshenin evaporimeter was actually designed for observations of evaporation from snow (Gorshenin, 1948). Its size was $25 \times 30 \times 10 \mathrm{~cm}$ with an evaporation area of $750 \mathrm{~cm}^{2}$. The bottom of the evaporimeter was double: the first was mesh and the second was solid, with a tightly closing hole for draining the water. The mesh bottom of the evaporimeter allowed for accounting of (melt) water infiltration; a sufficient height $(10 \mathrm{~cm})$ and a free flow of thawed water down under the grid approximate the processes of snow melting and evaporation to natural conditions.

Evaporimeter GGI-500-50 (later modified to GGI-50030 ) is a standard device for soil evaporation measurements 

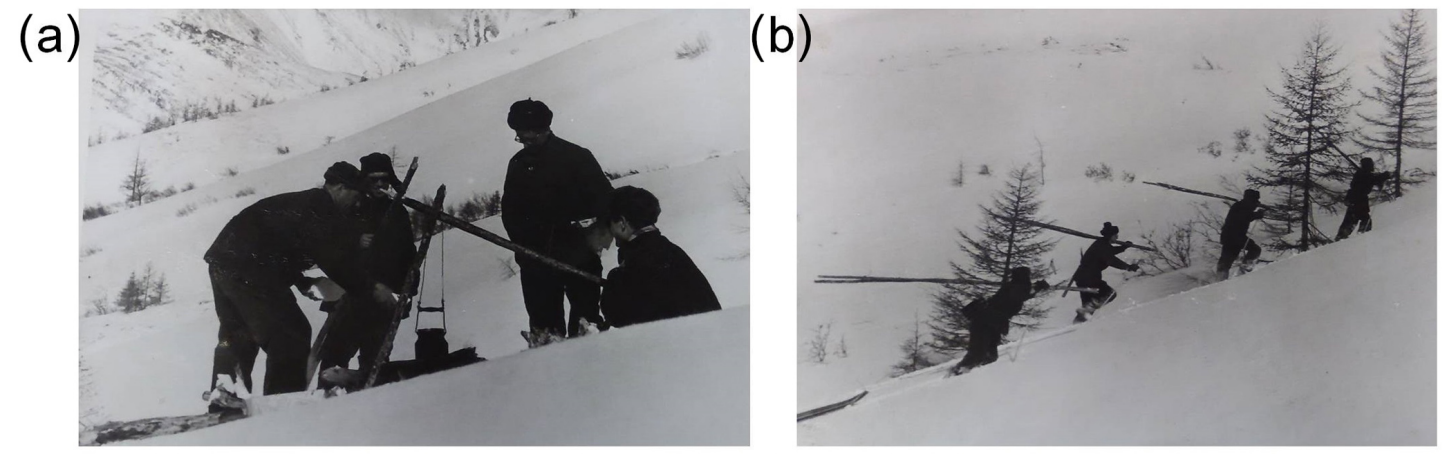

(c)

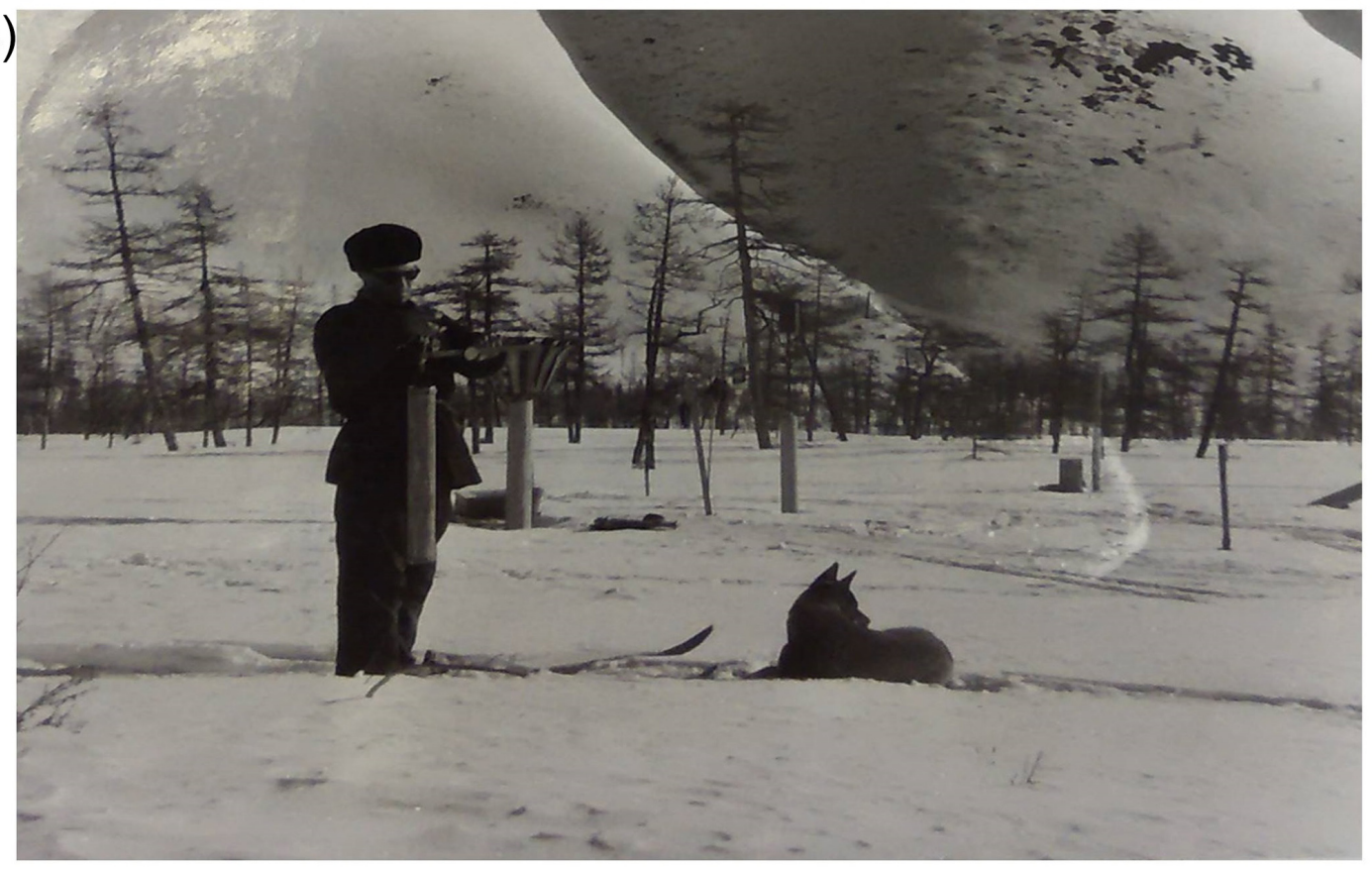

Figure 4. (a, b) Snow survey at the Kontaktovy creek catchment; (c) measurement of snow density, 1960 (photos from the KWBS archive, provided by S. I. Sushansky).

Table 2. Number of snow routes, their total length and number of measurement points - maximum and minimum values within the whole period of observations.

\begin{tabular}{llrrr}
\hline Watershed & Period & $\begin{array}{r}\text { Number of } \\
\text { snow routes }\end{array}$ & $\begin{array}{r}\text { Total length of } \\
\text { the route, } m\end{array}$ & $\begin{array}{r}\text { Amount of snow depth } \\
\text { measurement points }\end{array}$ \\
\hline Yuzhny & $1960-1997$ & 4 & $1400-1540$ & $144-154$ \\
Severny & $1950-1997$ & $4 / 10$ & $1950 / 2130$ & $23 / 207$ \\
Morozova & $1968-1997$ & $2 / 5$ & $960 / 2645$ & $98 / 534$ \\
Ugroza & $1983-1997$ & 1 & 1200 & 120 \\
Dozhdemerny & $1959-1971$ & 3 & $3240 / 5720$ & $327 / 575$ \\
Vstrecha & $1950-1997$ & $1 / 17$ & $2110 / 10850$ & $119 / 1091$ \\
Kontaktovy & $1960-1997$ & $2 / 4$ & $4830 / 13100$ & $485 / 1314$ \\
\hline
\end{tabular}

in Russia and the former USSR (Fig. 5b). It consists of two cylindrical vessels, one inside the other, and a watercollecting vessel. The bottom of the inner cylinder has openings; the core sample is placed in it. The quantity of water evaporated is determined from the difference in weight of the sample as measured over two successive observation periods.

From 1950 to 1953, five soil evaporation plots were opened at the sites with diverse underlying surfaces and different expositions and altitudes. The plots were equipped 

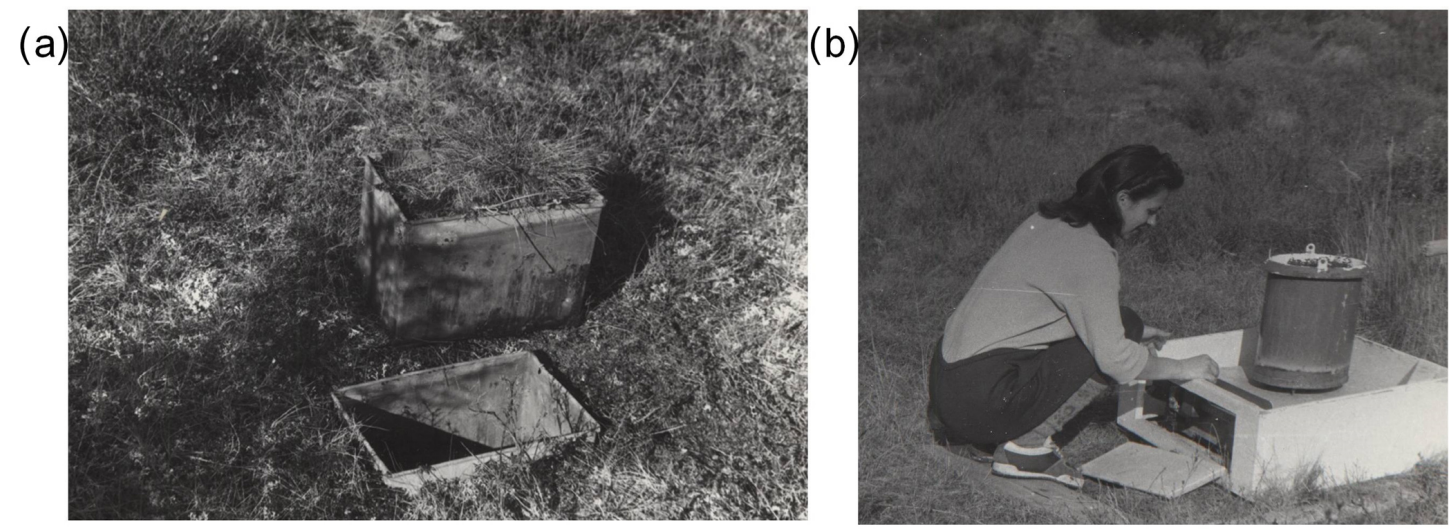

Figure 5. (a) Rykachev evaporimeter; (b) weighing the GGI-500-30 evaporimeter (Sushansky, 1989).

with the Rykachev and Gorshenin evaporimeters with evaporation area $1000 \mathrm{~cm}^{2}$. The observations until 1958 are considered to be approximate due to the absence of accompanying rain gauges and scales of the required accuracy.

From 1958 to 1966, the measurements were conducted at the soil evaporation plot, located near the Nizhnyaya weather station. The observations of evaporation were carried out with two evaporimeters GGI-500 and the Rykachev evaporimeter, precipitation - with a ground rain gauge (GR-28).

Three soil evaporation sites were established in different landscapes - in the Vstrecha (1967), Morozova (1971) and Yuzhny (1977) brooks basins. The measurements were carried out with standard weighing evaporimeters GGI-500-50, which, due to the physical proximity of permafrost, were changed to GGI-500-30, meaning that their height was decreased to $30 \mathrm{~cm}$.

The accuracy of soil evaporation observations was $0.1 \mathrm{~mm}$ (Konstantinov, 1968).

\subsection{Snow evaporation}

Snow evaporation observations were conducted at the KWBS from 1951, but only the data for the period 1968-1992 are considered to be consistent and reliable and is published in the described database. From 1968 to 1981, the observations were conducted with standard evaporimeter GGI-500-6 at weather plot Nizhnyaya. In 1981 the snow evaporation observations were transferred to the Kulu weather plot and lasted until 1992.

This measurement accounts for snow evaporation on the ground. In the conditions of the KWBS with larch as the main tree type, intercepted snow was only a temporary phenomenon because of cyclonic activity in January and February. Wind during the cyclones blows away snow from all trees except dwarf cedar, which is under snow for the greater part of the winter.

Observations of evaporation from snow were made mainly in the fall (September, October) and in the spring (May-
March). During winter months (January-February), the observations were made only until 1973, because the amount of evaporation from snow proved to be extremely insignificant for water balance. In the spring, during the intensive snowmelt, additional weighing of the evaporimeters was carried out every $3-6 \mathrm{~h}$. In the database, the evaporation values for night $(20-8 \mathrm{~h})$ and daytime $(8-20 \mathrm{~h})$ intervals are presented, only those values that correspond to a full $12 \mathrm{~h}$ period of observations are published.

The accuracy of snow evaporation measurements is $0.01 \mathrm{~mm}$.

\subsection{Thaw/freeze depth}

Since 1952, the observations of permafrost seasonal thaw dynamics have been conducted at the KWBS. Danilin cryopedometers (frost tubes) were installed at permafrost observation sites (Snyder et al., 1971) which mostly were located in the approximate vicinity of Nizhnyaya and Verkhnyaya weather stations at the slopes with different aspects and landscapes.

The cryopedometer designed by A.I. Danilin consists of a rubber tube $1 \mathrm{~cm}$ in external diameter and calibrated to an accuracy of $1 \mathrm{~cm}$. The tube is filled with distilled water, closed at both ends and lowered into a casing (an ebonite pipe) installed in a borehole in the soil. In order to measure the depth of freezing, the rubber tube is taken from the casing and the lower end of the ice column in the tube is determined (Manual of the water balance stations, 1973).

Despite the fact that permafrost observation sites were equipped with special bridges for observers to come close, eventually surface damage in the area where the device was installed began to influence thaw depth (Sushansky, 1988).

During 1952-1997 38 cryopedometers were functioning in total. 

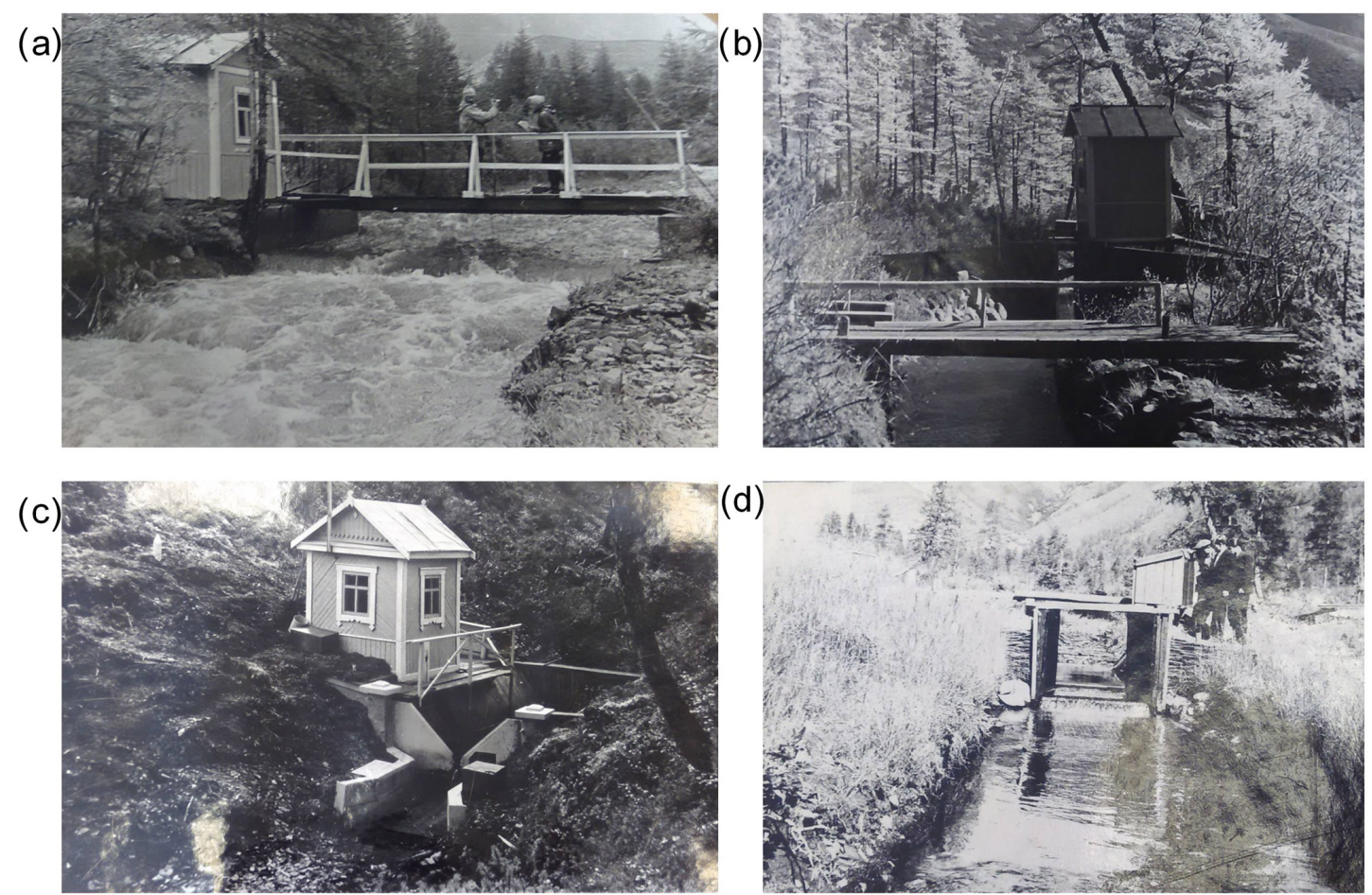

Figure 6. Runoff observations: (a) runoff gauge at the Kontaktovy creek, 1979; (b) runoff gauge at the Dozhdemerny creek, 1959; (c) runoff gauge at the Yuzhniy creek, 1960; (d) runoff gauge at the Vstrecha creek, 1953 (photos from the KWBS archive, provided by S. I. Sushansky).

\subsection{Streamflow}

Runoff observations were carried out at 10 catchments: the Kontaktovy creek (gauges Verkhny, Sredny, and Nizhny), and brooks Morozova, Yuzhny, Vstrecha, Vstrecha (the mouth), Dozhdemerny, Severny, and Ugroza (Fig. 6). Key characteristics of the catchments are listed in Table 7.

All the water level gauges were equipped with "Valdai" water level recorders, as well as needle and hook water level gauges. In spring and autumn, when recorders did not work properly due to ice on the creeks, discharge was measured more frequently, every $4 \mathrm{~h}$. To prevent the recorder floats from freezing, the wells were heated with electric bulbs.

At the micro-watersheds of the Morozova and Yuzhny brooks, runoff was measured by means of a V-notch weir, and at Severny brook, with a flow measuring flume.

In the database, mean daily values of streamflow are presented.

Originally, daily discharges were published in Observation Reports in $\mathrm{L} \mathrm{s}^{-1}$ with accuracy of three significant figures, but not more accurately than $0.01 \mathrm{~L} \mathrm{~s}^{-1}$ for runoff gauges equipped with weir or flume. For gauges with a natural channel for discharges more than $1000 \mathrm{~L} \mathrm{~s}^{-1}$ the rounding to three significant figures was performed, for discharges less than $100 \mathrm{~L} \mathrm{~s}^{-1}-$ to two significant figures, but not more precise than $1 \mathrm{Ls}^{-1}$.

Small discharges, which are less than $0.05 \mathrm{~L} \mathrm{~s}^{-1}$ for the gauges equipped with hydrometric facilities and less than
$0.5 \mathrm{~L} \mathrm{~s}^{-1}$ for larger watershed gauges, were published in $\mathrm{Ob}$ servation Reports as 0.00 and 0 respectively. The periods with no runoff because of drying and freezing were marked with special symbols.

In the database, water discharges are converted to $\mathrm{m}^{3} \mathrm{~s}^{-1}$; the number of significant figures was preserved, but the values 0.00 and 0 , as well as special symbols for freeze and dry periods, are indicated as 0 .

In 1969-1997 the data on the accuracy of discharge were published for several runoff gauges in the Observation Reports. They consist of information about (1) the number of measured discharges used to create the stage curve, (2) the percentage of the curve stage amplitude described by measured discharges, and (3) the percentage of stage curve extrapolation in both directions. These data are available for one or several runoff periods (ranging from 1-3 days to more than 2 continuous months) per year depending on how many stage curves were applied for each gauge. Figure 7 shows the boxplot of the percentage of stage curve extrapolation for seven runoff gauges for the period 1969-1997. Though the information is given not for individual discharges but rather for the periods, one may assume that the extrapolation is conducted for extreme events and analyse presented boxplots from this point of view. For most gauges the interquartile range (IQR) lies within $-3+5 \%$ limits; the tails $(1.5 \times \mathrm{IQR})$ exceed $\pm 10 \%$ for only two of seven gauges. 


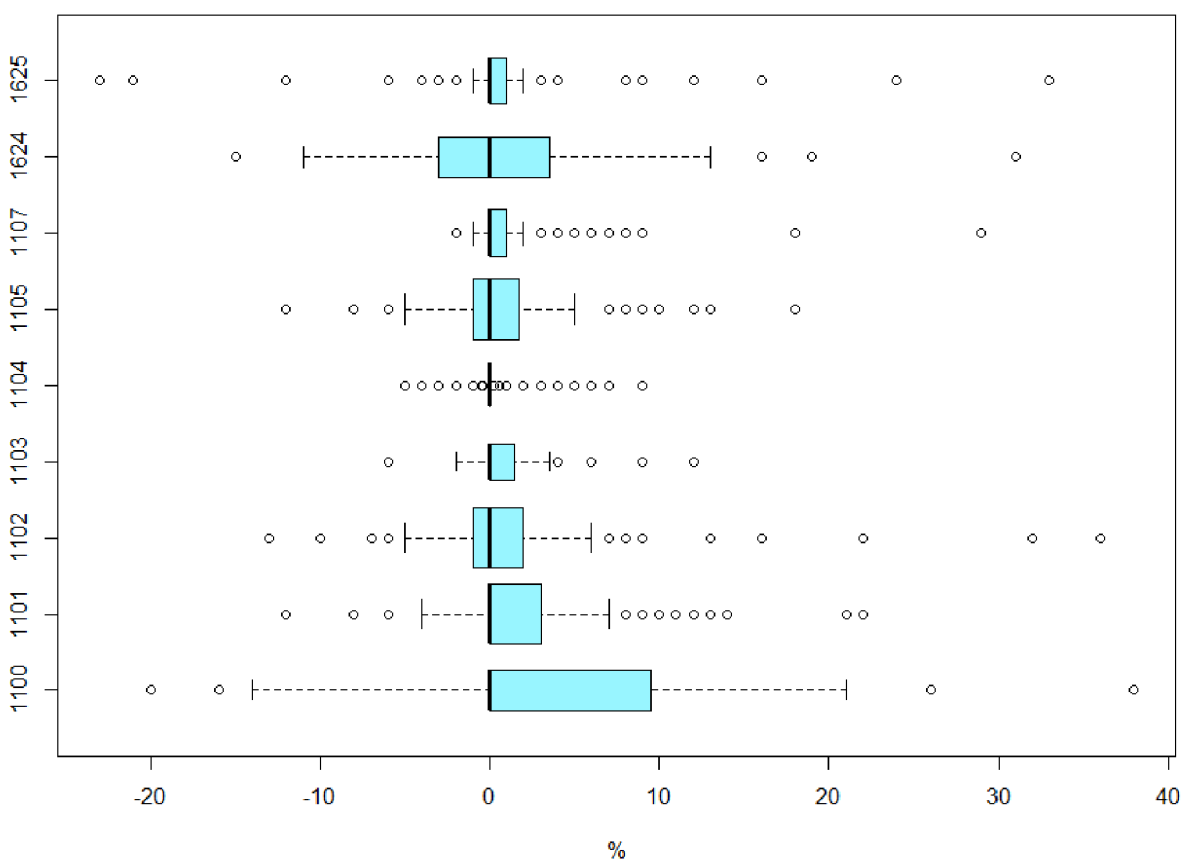

Figure 7. Percentage of stage curve extrapolation boxplots, 1969-1997. Here the boxes show the interquartile range (IQR), and the whisks present the border of $\pm 1.5 \times \mathrm{IQR}$.

The data on measured and estimated instantaneous maximum and minimum discharges are available for the period 1983-1997. We calculated the percent difference between those values and built the boxplots for maximum and minimum discharges (Fig. 8). Mostly estimated maximum instantaneous discharges exceed measured ones by $3-20 \%$. Minimum instantaneous discharges (above 0) are underestimated in comparison with measured ones by a wider range (5-35\%).

The data on the accuracy of flow discharges are presented in the database and may be analysed on a single-event basis.

\section{Results}

\subsection{Meteorological variables and precipitation}

The climate of the study area is severely continental with harsh long winters and short but warm summers. Average annual temperature at the Nizhnyaya meteorological plot during $1949-1996$ is $-11.3^{\circ} \mathrm{C}$. Mean monthly temperature in January was $-33.6{ }^{\circ} \mathrm{C}$, in July $+13.2^{\circ} \mathrm{C}$ (Figs. 9, 10). The absolute minimum daily temperature of $-53.0^{\circ} \mathrm{C}$ was registered in 1982 and the absolute maximum daily temperature was $+22.8^{\circ} \mathrm{C}$ (1988). The period of negative air temperatures lasts from October to April, freeze-free period is, on average, 130 days long.

Air temperature inversions are observed at the KWBS. In December, the air temperature gradient reaches +2.0 , in May it accounts for $-0.5^{\circ} \mathrm{C}$ per $100 \mathrm{~m}$ of elevation respectively.
The average air humidity at the Nizhnyaya station is $3.6 \mathrm{mb}$, reaching its maximum and minimum values of 9.8 and $0.4 \mathrm{mb}$ in July and December respectively.

Total cloudiness at the Nizhnyaya station has an average annual value of 7.0 and does not change considerably through the year. Its minimum and maximum values are 5.9 and 8.0 in March and July. The lower cloudiness dynamic is more significant: its mean monthly value changes from 0.5 to 4.7 in March to July with an average value of 2.2 points.

Mean wind velocity is more than twice as high at Verkhnyaya station (1220 m a.s.l.) in comparison with Nizhnyaya station $(850 \mathrm{ma}$ a.s.l.) and amounts to 3.0 and $1.3 \mathrm{~m}$ $\mathrm{s}^{-1}$ accordingly. The average monthly value changes from 0.83 in December to 1.70 in May at Nizhnaya, and from 2.7 in November and February to 3.4 in May. Maximum daily wind speed amounted to 16 and $36 \mathrm{~m} \mathrm{~s}^{-1}$ at Nizhnyaya and Verkhnyaya.

Precipitation at Nizhnyaya meteorological plot from 1969 (the year when wetting losses were introduced) to $1997 \mathrm{var}-$ ied from 229 (1991) to 474 (1990) mm per year with a mean value of $362 \mathrm{~mm}$. After introducing wetting losses correction to the period 1949-1968 and computing average mean amount from 1949 to 1997, the mean annual value decreased to $351 \mathrm{~mm}$. Maximum and minimum monthly amount of precipitation at Nizhnyaya station was observed in July and March and correspond to 72 and $8 \mathrm{~mm}$ respectively for the whole period of observations 1949-1997 (Figs. 9, 10).

Maximum daily amount of precipitation at Nizhnyaya station was observed in June 1968, reaching $48.1 \mathrm{~mm}$. On aver- 
(a)

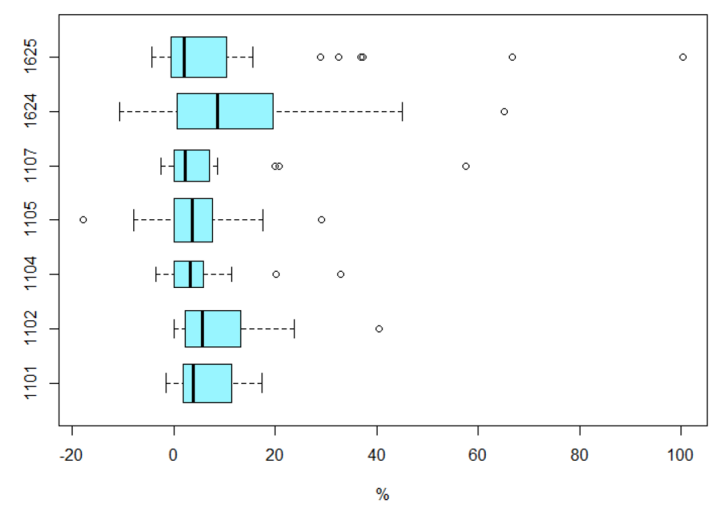

(b)

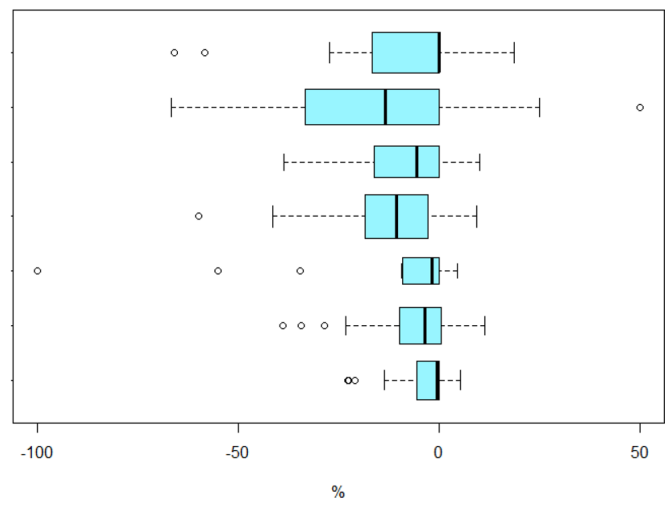

Figure 8. Difference between measured and estimated maximum (a) and minimum (b) instantaneous discharge, 1982-1997.

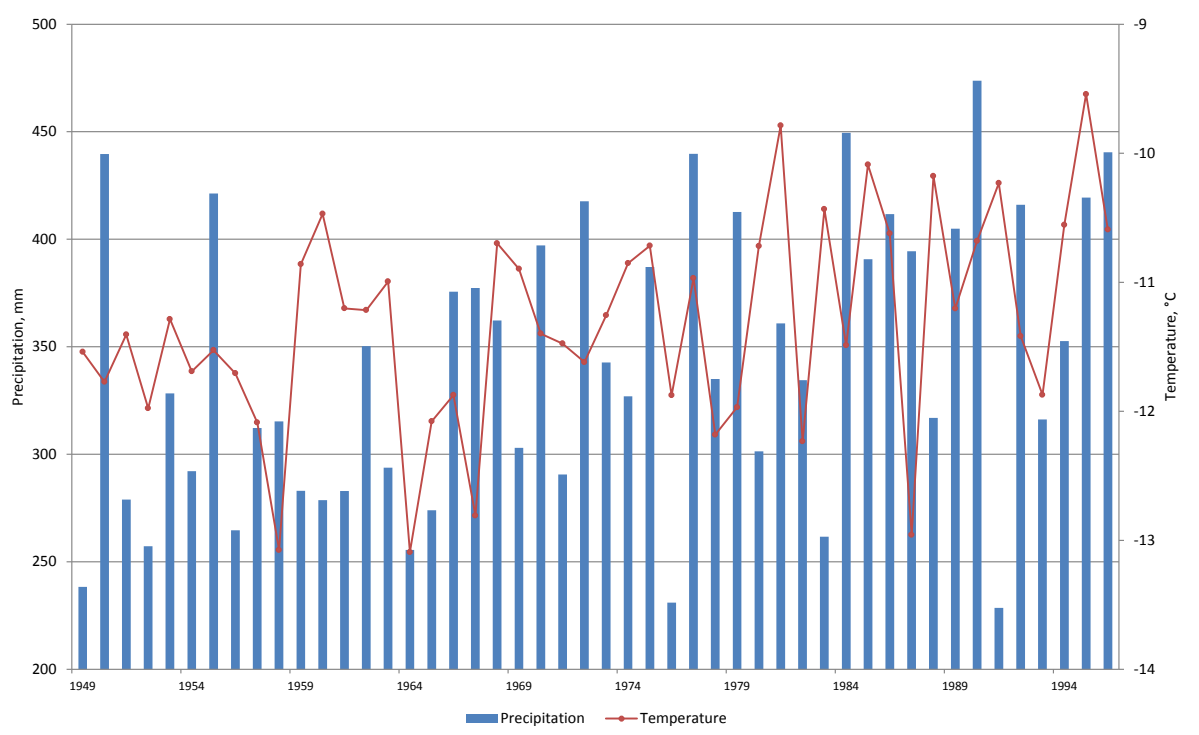

Figure 9. Annual precipitation $(\mathrm{mm})$ and air temperature $\left({ }^{\circ} \mathrm{C}\right)$ at Nizhnyaya weather station, $1949-1996$.

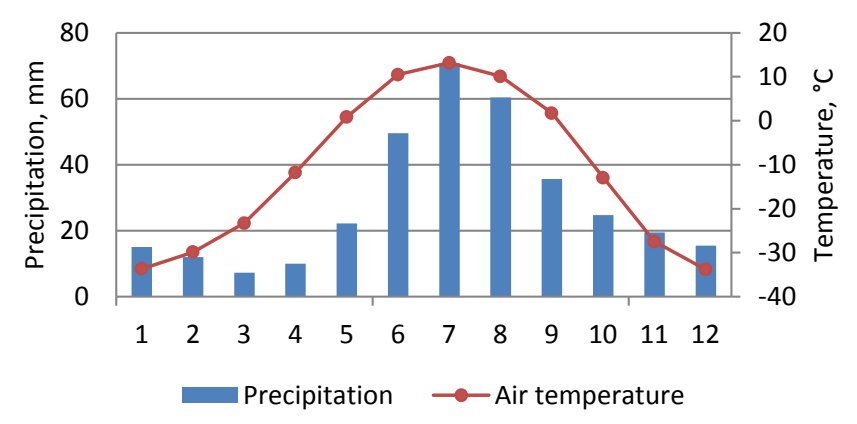

Figure 10. Mean monthly precipitation $(\mathrm{mm})$ and air temperature $\left({ }^{\circ} \mathrm{C}\right)$ at Nizhnyaya weather station, $1949-1996$. age for the period of 50 years, maximum daily precipitation per year amounted to $26 \mathrm{~mm}$.

\subsection{Snow cover}

On average, a stable snow cover at the KWBS is formed in the first weeks of October, and melts in the third week of May (1949-1996). The KWBS area is characterized by an increase in the thickness of the snow cover over this period due to the absence of thaws during the snow season. In the open treeless and watershed divide areas, the redistribution of snowpack due to wind blow is observed.

The averages for the watershed mean, maximum and minimum snow water equivalent (SWE) before spring freshet estimated based on snow survey results at Kontaktovy-Nizhny amount to 121, 213 (1985) and 59 (1964) mm respectively in the 1960-1997 period. In general, rocky talus and tun- 
Table 3. Mean, maximum and minimum observed snow water equivalent (SWE) $(\mathrm{mm})$ before spring freshet at different landscapes of the Kontaktovy creek watershed, 1960-1997.

\begin{tabular}{lrrr}
\hline \multirow{2}{*}{ Landscape } & \multicolumn{3}{c}{ SWE } \\
\cline { 2 - 4 } & mean & $\max (1985)$ & $\min (1964)$ \\
\hline Forest & 144 & 265 & 79 \\
Dwarf cedar tree bush & 127 & 247 & 39 \\
Rocky talus & 100 & 182 & 46 \\
Boulders & 66 & $127(1974)$ & 2 \\
Kontaktovy creek & 121 & 213 & 59 \\
\hline
\end{tabular}

Table 4. Mean, maximum and minimum snow water equivalent (SWE) $(\mathrm{mm})$ before spring freshet at different watersheds within the KWBS.

\begin{tabular}{lrrrr}
\hline \multirow{2}{*}{ Watershed } & \multirow{2}{*}{ Period } & \multicolumn{3}{c}{ SWE } \\
\cline { 3 - 5 } & & mean & $\max$ & $\min$ \\
\hline Yuzhny & $1960-1997$ & 121 & 166 & 70 \\
Severny & $1950-1997$ & 126 & 232 & 62 \\
Morozova & $1968-1997$ & 161 & 298 & 71 \\
Ugroza & $1983-1994$ & 133 & 200 & 93 \\
Dozhdemerny & $1959-1971$ & 82 & 111 & 53 \\
Vstrecha & $1951-1997$ & 123 & 213 & 60 \\
\hline
\end{tabular}

dra bush landscapes are characterized by lower SWE due to wind blowing. Much snow is accumulated in the forest landscape. However, at the Morozova brook watershed which is fully covered by rocky talus landscape, mean SWE before snowmelt was estimated as $161 \mathrm{~mm}$, with the maximum value of $298 \mathrm{~mm}$ observed in 1985 reaching on average $0.99 \mathrm{~m}$ snow height (Tables 3 and 4, Fig. 11).

\subsection{Soil and snow evaporation}

The highest values of soil evaporation during the summer period were observed at the larch forest (site 9) and reached $136 \mathrm{~mm}$. At a similar landscape (site 1), this value is lower, at $119 \mathrm{~mm}$, which indicates the influence of local factors. The lowest values of soil evaporation are $104 \mathrm{~mm}$ at the plot located at dwarf cedar tree bush (site 7). In July, soil evaporation values range from 33 to $40 \mathrm{~mm}$, depending on the landscape. In September, the contribution of evaporation decreases to 14-24 mm (Table 5).

Average values of annual soil evaporation were previously estimated by Semenova et al. (2013) and Lebedeva et al. (2017) based on the partial KWBS dataset as the following: $140 \mathrm{~mm}$ for larch and swampy sparse growth forest, $110 \mathrm{~mm}$ in dwarf cedar and alder shrubs of the tundra belt, and about $70 \mathrm{~mm}$ for rocky talus.

The average values of evaporation from snow in $\mathrm{mm}$ per day as determined from measurement data are as follows: January-February - -0.04 (condensation); March -+0.09 ;

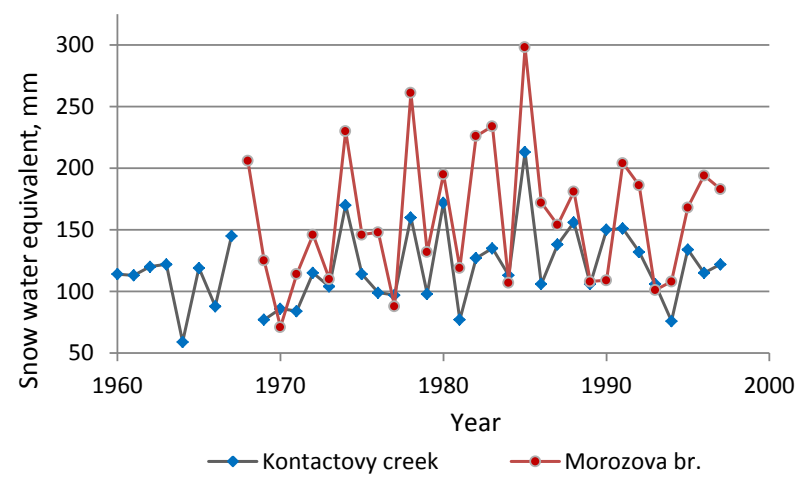

Figure 11. Snow water equivalent at the Kontaktovy creek and Morozova brook.

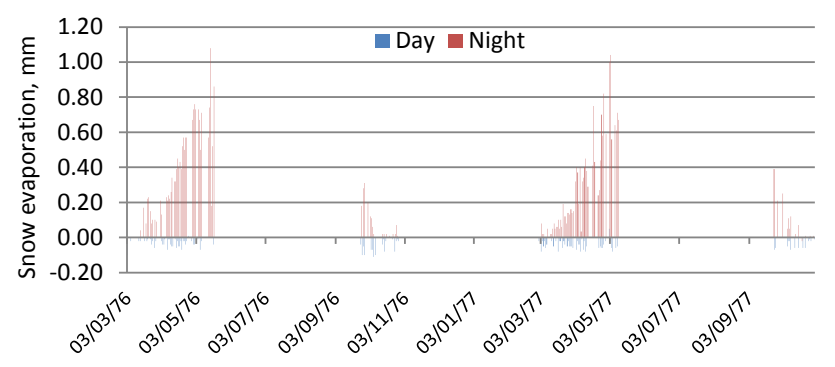

Figure 12. Snow evaporation $(\mathrm{mm})$ during the day and night periods, 1976-1977.

April - +0.40; May - +0.74; September -+0.20 ; October -+0.01 . Typical values of evaporation from snow for 19761977 are presented in Fig. 11.

\subsection{Thaw/freeze depth}

The longest observation period is 33 continuous years (cryopedometer 17.5 located at the forest with bushes, maximum thawing is $130 \mathrm{~cm}, 1964-1997)$. The deepest values of thawing were observed in rocky talus landscape and can reach more than $240 \mathrm{~cm}$. The shallowest values of thawing range from 60 to $70 \mathrm{~cm}$ at swampy forest. Thawing of soils at the forest zone varies in large ranges and depends on the location of the cryopedometer at a slope (Table 6, Fig. 13).

Lebedeva et al. (2014) reviewed the patterns of soil thaw/freeze processes and their impact on hydrological processes based on the analysis and modelling of the data at the cryopedometers in the main landscapes of the KWBS: rocky talus, mountain tundra with dwarf tree brush, moss-lichen cover and sparse-growth forest or larch forest.

\subsection{Streamflow}

Flow at the KWBS begins in May, and most of it occurs in summer. At the outlet of the KWBS Kontaktovy creek at Nizhny, 33, 24 and $20 \%$ of flow occurs in June, July and 
Table 5. Mean evapotranspiration (mm) from June to September at different landscapes of the KWBS. n/a - not applicable.

\begin{tabular}{|c|c|c|c|c|c|c|c|c|c|}
\hline Site no. & Landscape & Period & Elevation, $\mathrm{m}$ & Slope aspect & Jun & Jul & Aug & Sep & Total* \\
\hline 1 & Larch forest & $1962-1997$ & 850 & $\mathrm{n} / \mathrm{a}$ & 35 & 37 & 30 & 17 & 119 \\
\hline 6 & Swampy sparse growth forest & 1969-1982 & 970 & North & 37 & 38 & 30 & 19 & 124 \\
\hline 7 & Dwarf cedar tree bush & 1972-1997 & 1020 & $\mathrm{n} / \mathrm{a}$ & 30 & 33 & 25 & 17 & 104 \\
\hline 8 & Dwarf cedar tree bush & 1976-1997 & 900 & South & 47 & 40 & 30 & 14 & 131 \\
\hline 9 & Larch forest & 1982-1992 & 669 & West & 36 & 39 & 37 & 24 & 136 \\
\hline
\end{tabular}

* The sum for the warm period.

Table 6. Maximum depth of thawing at the different landscapes.

\begin{tabular}{|c|c|c|c|c|c|}
\hline $\begin{array}{l}\text { Site } \\
\text { no. }\end{array}$ & Watershed & Landscape & Period & $\begin{array}{r}\text { Elevation, } \\
\mathrm{m}\end{array}$ & $\begin{array}{l}\text { Maximum depth } \\
\text { of thawing, cm }\end{array}$ \\
\hline 1 & Kontaktovy & Forest & $1954-1966$ & 841 & 150 \\
\hline 6 & Dozdemerny & Rocky talus & $1960-1965$ & 1048 & $>240$ \\
\hline 9 & Severny, Ugroza & Rocky talus & $1954-1966 ; 1977-1978$ & 986 & 168 \\
\hline 12 & Vstrecha, Severny & Dwarf cedar tree bush at rocky talus & 1954-1962; 1966-1968; 1971-1997 & 866 & 157 \\
\hline 15 & Dozdemerny & Dwarf cedar tree bush at rocky talus & $1958-1968 ; 1970-1982$ & 952 & $>150$ \\
\hline 17 & Vstrecha & Forest & $1960-1965 ; 1969$ & 914 & $>124$ \\
\hline $18 \mathrm{bh} 7$ & Kontaktovy & Peat bogs & $1959-1960$ & 835 & 69 \\
\hline 18 bh8 & Kontaktovy & Peat bogs & $1959-1960$ & 835 & 64 \\
\hline
\end{tabular}

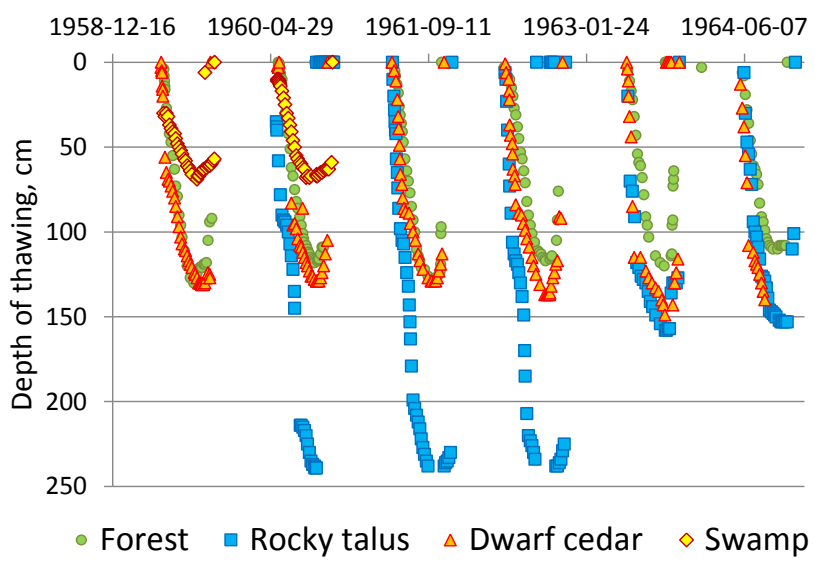

Figure 13. Depth of ground thawing at the different landscapes of the KWBS.

August respectively. For the summer period, rainfall floods are typical (Fig. 14).

Small brooks freeze completely in October. Surface flow stops at the channel of the Kontaktovy creek at the Nizhny gauge in November, but there is evidence that the river valley talik located lower than the Kontaktovy-Nizhny gauge experiences runoff until the beginning of snowmelt, which is evidenced by a continuous drop in levels in hydrogeological wells (Glotov, 2002).

Annual runoff of the Kontaktovy stream basin with area $21.3 \mathrm{~km}^{2}$ (average altitude $1070 \mathrm{~m}$ ) is $281 \mathrm{~mm}$ for the period 1948-1997, it increases with elevation and at the Morozova

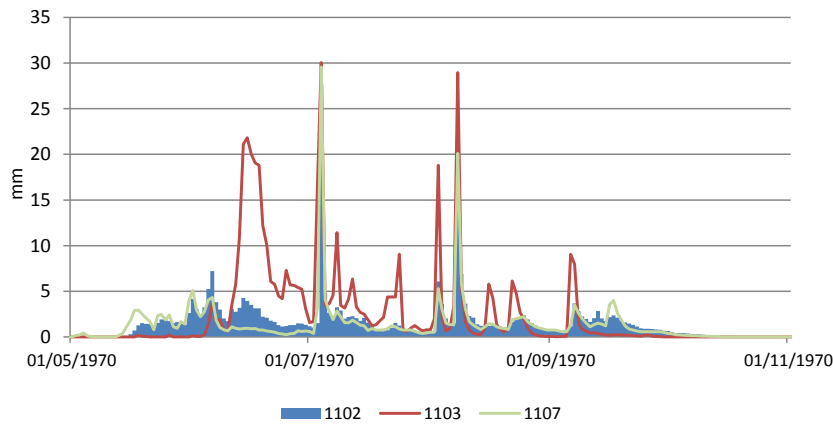

Figure 14. Flow depth $(\mathrm{mm})$ at the Kontaktovy creek - Nizhny (1102), Severny brook (1107) - south-facing slope with cedar dwarf bush landscape, and Morozova brook (1103) - rocky talus landscape at watershed divides, 1970.

catchment (mean elevation $1370 \mathrm{~m}$, basin area $0.63 \mathrm{~km}^{2}$ ) reaches $453 \mathrm{~mm}$ (1969-1996). The flow from south-facing (Severny) and north-facing (Yuzhny) micro-watersheds with area of 0.38 and $0.27 \mathrm{~km}^{2}$ are 227 and $193 \mathrm{~mm}$ for the period 1960-1997 respectively.

Maximum daily discharge was observed in August 1979 and amounted to $7.6 \mathrm{~m}^{3} \mathrm{~s}^{-1}$ (daily flow $30 \mathrm{~mm}$ ) and $0.438 \mathrm{~m}^{3} \mathrm{~s}^{-1}(60 \mathrm{~mm})$ at the Kontaktovy-Nizhny and Morozova watersheds respectively. 


\subsection{Changes in hydrometeorological elements over the 50-year period 1948-1997}

The time series of flow characteristics and basic meteorological elements were evaluated for stationarity, in relation to the presence of monotonic trends, with Mann-Kendall and Spearman rank-correlation tests, at the significance level of $p<0.05$ (Mann, 1945; Kendall, 1975). If both tests proved a trend, a serial correlation coefficient was tested. With the serial correlation coefficient $r<0.20$, the trend was considered reliable. In the case of $r \geq 0.20$, to eliminate autocorrelation in the input series "trend-free pre-whitening" procedure (TFPW), described by Yue et al. (2002), was carried out. "Whitened" time series were repeatedly tested with a MannKendall non-parametric test. The trend value was estimated with a Theil-Sen estimator (Sen, 1968).

The annual air temperature at Nizhnyaya station increased by $1.1{ }^{\circ} \mathrm{C}$; positive trends are observed in March and October, accounting for the rise in temperature by 2.3 and $3.3^{\circ} \mathrm{C}$ correspondingly. The annual sum of precipitation has grown by $74 \mathrm{~mm}(21 \%)$. Maximum annual daily precipitation has also increased by $8 \mathrm{~mm}$, or $31 \%$.

The analysis of monthly and annual flow $(\mathrm{mm})$ for the Kontaktovy creek - Nizhny - from 1948 to 1997 has revealed the changes in hydrological regime in those 50 years of runoff observations (Fig. 15). Positive trends of monthly flow are identified in May, amounting to $29 \mathrm{~mm}$, or $92 \%$, as well as in October $(5.7 \mathrm{~mm}, 166 \%)$ and November $(0.35 \mathrm{~mm}$, $252 \%$ ). The annual flow trend increased by $67 \mathrm{~mm}$, or $24 \%$. These results confirm the general situation of increasing low flow which is observed in Siberia (Tananaev et al., 2016) and North America (Yang et al., 2015; St. Jacques and Sauchyn, 2009).

\section{Water balance estimation}

The study of the water balance of watersheds is aimed at assessing the quantitative changes in its components. In the northern regions, where climate change is more pronounced than in other parts of the world (ACIA, 2004) and standard hydrological network is shrinking (Shiklomanov et al., 2002), the assessment of the water balance and its future change is important.

The Northern Research Basins Water Balance (2004) book compiles the main results of water balance studies in the northern watersheds in last century, such as Wolf Creek (Janowicz et al., 2004), the Kuparuk River (Lilly et al., 1998), Scotty Creek (Quinton et al., 2004), the Nelka River (Vasilenko, 2004), and the Kontaktovy creek of the KWBS (Zhuravin, 2004).

In this section, the results of rough estimation of mean annual water balance for three micro-watersheds with area less than $1 \mathrm{~km}^{2}$ representative for main landscapes of studied territory (Severny, Yuzhny, Morozova) are presented and compared with the assessments made by other authors. The estimation of water balance for the whole watershed of Kontaktovy creek requires special analysis and does not lie in the scope of this paper; only the results of other authors are summarized.

A general form of the water balance equation (in $\mathrm{mm}$ ) is used as the following:

$\mathrm{SWE}+P_{\text {rain }}+\Delta P_{\text {corr }}-\mathrm{ET}-E_{\text {snow }}-R=\eta$.

Here SWE is the average value of the snow water equivalent before spring freshet from snow survey data. For Morozova watershed SWE was usually measured in the beginning of May, while the precipitation observations were conducted from the beginning of June; therefore, we increased SWE at this watershed by $36 \mathrm{~mm}$, which is the average precipitation in May at ground rain gauge no. 42 (1400 m a.s.l.).

$P_{\text {rain }}$ is the total sum of daily rainfall precipitation during the warm period from the rain gauges located within the studied watersheds. The data before 1969 were corrected for wetting losses according to the Manual for hydrometeorological stations (1969).

For Severny and Yuzhny watersheds, rainfall precipitation $P_{\text {rain }}$ is calculated as the total sum of precipitation in the May-August period and half of average precipitation in September accounting for the air temperature transition from positive to negative which usually occurs in the middle of September at rain gauge nos. 5 (880 m a.s.l.) and 20 (900 m a.s.l.) respectively.

For Morozova watershed, which is on average $300 \mathrm{~m}$ higher than Severny and Yuzhny, $P_{\text {rain }}$ consists of the sum of precipitation for the period from June to August estimated based on the data from daily precipitation data of rain gauge no. 38 (1200 m a.s.l.).

$\Delta P_{\text {corr }}$ is wind and evaporation correction of warm period rainfall precipitation calculated using the wind speed data from Nizhnyaya and Verknyaya stations based on the recommendations from Manual for hydrometeorological stations (1969).

ET, soil evapotranspiration, is calculated using average annual values for the main landscapes of the KWBS estimated by Semenova et al. (2013) and Lebedeva et al. (2017) with the account of their distribution across the studied watersheds.

Evaporation from snow $E_{\text {snow }}$ is assessed as the following:

$E_{\text {snow }}=0.40 \cdot d_{\text {Apr }}+0.74 \cdot d_{\text {May }}$,

where $d_{\mathrm{Apr}}$ and $d_{\text {May }}$ are average numbers of days in April and May between the date of maximum SWE and its full melt; 0.40 and 0.74 are average values of snow evaporation in April and May estimated based on observed data.

$R$ is observed runoff, and $\eta$ is the residual.

Possible members of water balance equation such as the changes in surface storage (lakes, wetlands, reservoirs, channels, etc.), subsurface storage of groundwater and the storage of the unsaturated zone are estimated as zero and not accounted for in long-term annual estimation. 

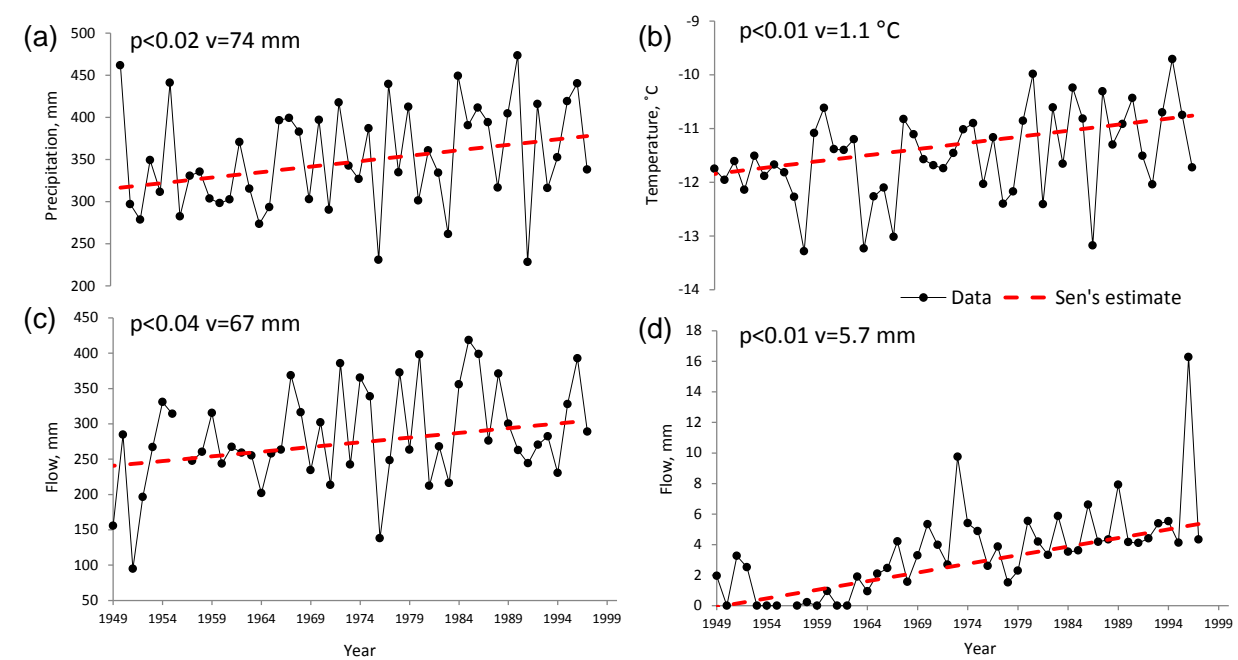

Figure 15. Trends of hydrometeorological elements, 1949-1997. (a, b) Annual precipitation (mm) and air temperature $\left({ }^{\circ} \mathrm{C}\right)$ at the Nizhnyaya station; (c, d) annual and October flow (mm) at the Kontaktovy creek - Nizhny. $p$ - statistical significance; $v$ - trend value.

Table 8 shows estimated distribution of water balance components for three small watersheds. All main components of water balance were assessed independently on the basis of direct observations. At two watersheds, the water balance discrepancy calculated as the difference between precipitation, runoff and total evaporation, is positive and varies from 43 to $57 \mathrm{~mm}$ which is about 11 and $14 \%$ of calculated total precipitation. The water balance error at the Morozova watershed, which is completely formed of rocky talus, is negative and amounted to $68 \mathrm{~mm}$ or $14 \%$ from total precipitation. Though we did not use for calculations the data of solid precipitation, Sushansky (2002) assessed snow under-

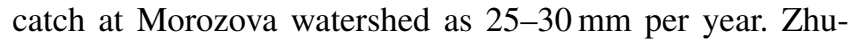
ravin (2004) mentioned that significant errors are possible at the sampling depth of snowpack profile in the areas covered with the Siberian dwarf-pine which is covered by snow during winter. He assessed the error of SWE estimation in such areas as $15 \%$ of the measured value. We would suggest that measuring SWE at rocky talus watershed where some areas are covered by boulders could cause the error of comparable magnitude.

The estimated runoff coefficient amounts to 56, 51 and $95 \%$ of precipitation for the Severny, Yuzhny and Morozova watersheds respectively. Considering the high runoff coefficient for the rocky talus landscape, the large proportion of the KWBS area (34\%) covered by this type of underlying surface (Fig. 2b) and a significant uncertainty of water balance estimation for the Morozova creek given the availability of observed data, correct assessment of water balances for larger areas would be difficult to determine.

Table 8 presents the comparison of water balance calculations for three micro-watersheds of the KWBS performed by different authors. While in this research SWE from snow surveys was taken as the estimate of winter precipitation, both
Lebedeva et al. (2017) and Zhuravin (2004) used observed precipitation data to assess this component of the water balance. The estimates of total precipitation vary due to different correction procedures applied (or not applied) by different authors. One may see that although all the authors used the same observed data on evaporation, its interpretation has provided the variation in results (Table 8 ). Also, a low closure error does not always confirm the correctness of estimation as, for example, Lebedeva et al. (2017) neither applied any bias correction to precipitation nor accessed the value of snow evaporation. Thus a low closure error may mask errors in multiple components which cancel each other out.

For the main KWBS watershed, the Kontakovy creek $\left(21.3 \mathrm{~km}^{2}\right)$, Zhuravin (2004) provided the following estimates of water balance for the period 1970-1985: precipitation $-405 \mathrm{~mm}$, evaporation $-137 \mathrm{~mm}$, runoff $-296 \mathrm{~mm}$, discrepancy error - $-28 \mathrm{~mm}(7 \%)$. Lebedeva et al. (2017) calculated the same values for 1949-1990 as 390, 281, 114 and $-5 \mathrm{~mm}(1 \%)$ respectively.

The presented results confirm that accurate numerical estimation of water balance elements even using available measurements is complicated (Kane and Yang, 2004) and subjective. Therefore it is important to make raw observational data available for the scientific community as described in this paper.

\section{Data availability}

All data presented in this paper are available from "PANGAEA. Data Publisher for Earth and Environmental Science" (see Makarieva et al., 2017, https://doi.org/10.1594/PANGAEA.881731). 


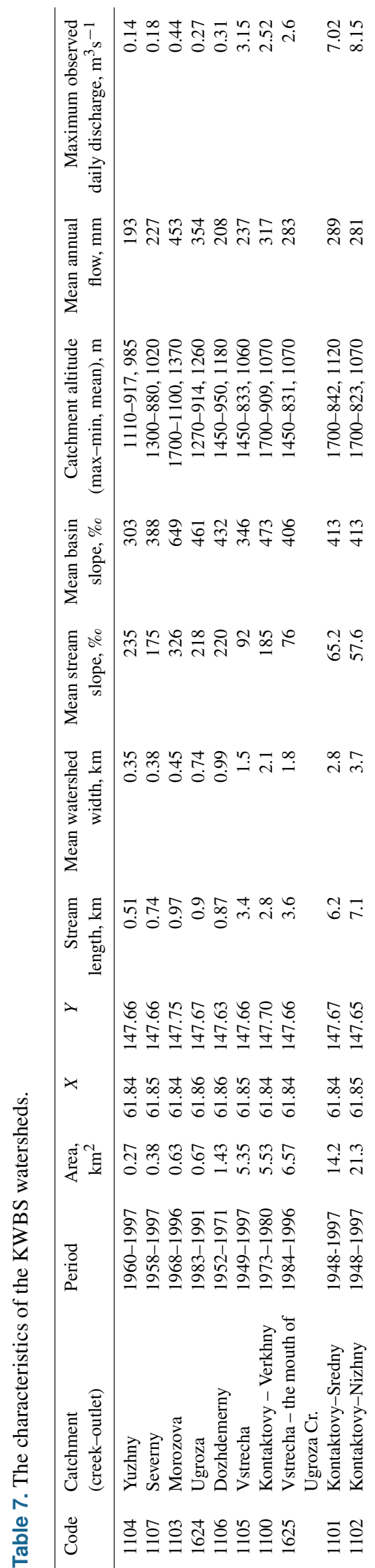

The directory includes 13 elements:

1. daily precipitation time series at 25 gauges within the KWBS, 1948-1997;

2. daily runoff time series at 10 gauges of the KWBS, 1948-1997;

3. evaporation time series at nine sites at the KWBS, 1950-1997;

4. meteorological observations at three sites of the KWBS, including the values of air temperature, water vapour pressure, vapour pressure deficit, atmospheric pressure, wind speed, low and total cloud amount, and surface temperature, 1948-1997;

5. monthly precipitation time series at 30 gauges within the KWBS, 1948-1997;

6. precipitation (10-day sum) time series at 21 gauges within the KWBS, 1962-1997;

7. precipitation (5-day sum) time series at 14 gauges within the KWBS, 1966-1997;

8. snow survey line characteristics at the KWBS, 19591997 ;

9. snow survey time series at different sites and landscapes within the KWBS, 1950-1997;

10. soil temperature time series at the Nizhnyaya meteorological station at the KWBS, 1974-1981;

11. thaw depth and snow height time series at different sites of the KWBS, 1954-1997;

12. snow evaporation time series at two sites of the KWBS, 1968-1992; and

13. information on streamflow data quality including the number of measured discharges used to derive the stage curve, the percentage of the curve stage amplitude described by measured discharges and the percentage of stage curve extrapolation in both directions for 7 gauges, 1969-1997; the data about measured and estimated instant maximum and minimum discharges for the period of 1983-1997.

The data are accompanied by the maps in ArcGIS format presenting the topography, main landscapes and equipment location.

\section{The future of the KWBS}

In summer 2016, with the assistance of Melnikov Permafrost Institute of Siberian Branch of Russian Academy of Science, 
Table 8. Water balance of the three micro-watersheds of the KWBS (mm, \%).

\begin{tabular}{lrrr|rrr|r|r}
\hline Watershed & \multicolumn{3}{c}{ Severny } & \multicolumn{3}{c}{ Yuzhny } & \multicolumn{2}{c}{ Morozova } \\
\hline Authors* & $\mathrm{M}$ & $\mathrm{L}$ & $\mathrm{Z}$ & $\mathrm{M}$ & $\mathrm{L}$ & $\mathrm{Z}$ & $\mathrm{M}$ & $\mathrm{L}$ \\
\hline Period & $1958-1997$ & $1959-1990$ & $1970-1985$ & $1960-1997$ & $1960-1990$ & $1970-1985$ & $1969-1997$ & $1969-1990$ \\
\hline SWE & 126 & - & - & 121 & - & - & $161+36$ & - \\
$P_{\text {rain }}$ & 263 & - & - & 232 & - & - & 225 & - \\
$\Delta P_{\text {corr }}$ & 25 & - & 70 & 22 & - & 65 & 55 & - \\
$P_{\text {total }}$ & 375 & 357 & 399 & 375 & 332 & 346 & 477 & 451 \\
ET & 113 & 120 & - & 124 & 132 & - & 73 & 73 \\
$E_{\text {Snow }}$ & 17 & 0 & - & 15 & 0 & - & 19 & 0 \\
$E_{\text {total }}$ & 130 & 120 & 139 & 139 & 132 & 147 & 92 & 73 \\
$R$ & 227 & 236 & 217 & 193 & 199 & 190 & 453 & 448 \\
$R(\%)$ & 56 & 66 & 54 & 51 & 60 & 55 & 95 & 99 \\
$\eta$ & 57 & 1 & 43 & 43 & 1 & 9 & -68 & -70 \\
$\eta(\%)$ & 14 & 0.3 & 11 & 11 & 0.2 & 3 & 14 & 16 \\
\hline
\end{tabular}

* M - current research (Makarieva et al.); L - Lebedeva et al. (2017); Z - Zhuravin (2004).

a group of specialists, consisting of representatives of different scientific institutions, conducted a reconnaissance survey of the KWBS in order to find out if it was possible to carry out scientific research and stationary monitoring of permafrost and hydrological processes at the station. Despite rather difficult logistic access to the KWBS, it was considered possible to organize accommodation and provision of the station for the period of summer expeditions. At first, the main goal of research resumption at the station would be a renewal of regular observations of runoff, meteorological elements and active layer dynamics at three small catchments (Morozova, Yuzhny, Severny) and the KWBS main-stream outlet (Nizhny gauge) using advanced equipment with automatic data recording. As a result, some unique runoff observations series - over 60 years long - will be continued, which will allow for evaluation of climatic impact on permafrost and provide a scientifically based forecast on current and future climate change impact on the hydrological regime.

During short 3- to 4-week field trips at the beginning and at the end of the warm (and hydrological) season, it would also be possible to study specific processes of runoff formation under permafrost conditions. Slope runoff occurs unevenly, and is concentrated in particular areas, the drainage zones or preferential path flows. Reconnaissance surveys of the Kontaktovy creek catchment at the KWBS territory, 2016, revealed that there are several types of such zones of slope runoff concentration. Another possible scientific task is to evaluate the role of cryogenic redistribution of runoff, which regularly occurs due to ice freezing-melting in coarsegrained slope deposits. Similar studies have already been carried out in mountain regions of permafrost, including the KWBS (Sushansky, 1990a, b, c; Bantsekina, 2001, 2002, 2003; Boyarintsev et al., 2006). Another research issue is the study of floodplain taliks (Mikhaylov, 2013) and aufeises (Alekseev, 2016) and their impact on hydrological processes in the mountainous part of the continuous permafrost zone. Field trips for a limited group of scientists could be covered with relatively modest financial support through research grants. In the future, the aim for the KWBS is to get back its status of a research station, to receive state funding, to obtain sponsor support from gold mining companies of the Magadan region and to become an international centre for complex studies in the field of permafrost hydrology.

The KWBS is situated in the region where monitoring of natural processes is extremely sparse. From 1986 to 1999, the number of hydrological gauge stations in Far East parts of Siberia decreased by $73 \%$ (Shiklomanov et al., 2002). Resumption of water balance observations and organization of complex research of permafrost, climate, and landscape, hydrological and hydrogeological processes based on data collected at the KWBS would make it possible to get new data representative of the understudied territory of the Arctic in the context of environmental changes. Considering the insufficient knowledge about this territory and available longterm data, the KWBS has the prospect of becoming a highly in-demand complex international centre for testing natural process models at different scales - from point to regional validation of remote sensing products and a place for multidisciplinary field research.

More than $20 \%$ of the Northern Hemisphere is covered by permafrost. Three of the four largest rivers of the Arctic Ocean basin flow through Siberia. Many studies highlight ongoing and intensifying changes in water, sediment and chemical fluxes at all spatial scales, but mechanisms of changes and future projections are highly uncertain. There are no research centres that could conduct focused studies of hydrological processes at catchments in the permafrost region in Russia. The KWBS incorporation into the international network for monitoring natural processes in cold regions (Interact, SAON, CALM, GTN-P, etc.) could significantly en- 
hance international cooperation for better understanding of cold-region hydrology for the last 70 years, present and future.

Nowadays, the resumption of continuous observations and research at the Kolyma station appears to be a critical task due to increased interest in the natural processes of the Arctic region. Present-day data, following the KWBS long-term observation series, could become a valuable indicator of climate change and a basis for studying its impact on the state of the permafrost and its associated hydrological regime. Currently, as the station infrastructure is still partly intact, and some of the specialists who worked at the KWBS are still active and willing to help, it is necessary to gain attention and support from the Russian and international scientific community regarding the renewal of the KWBS before it is too late.

\section{Conclusions}

The presented dataset describes water balance, hydrometeorological and permafrost-related components at a small research watershed in the mountainous permafrost zone of North-Eastern Russia, the Kolyma Water-Balance Station (KWBS). It includes 50 years of continuous daily meteorological and streamflow data for the main meteorological plot and runoff gauge of the KWBS and daily data of shorter periods for another two meteorological sites and nine runoff gauges. Meteorological data include values of air temperature, water vapour pressure, vapour pressure deficit, atmospheric pressure, wind speed, low and total cloud amount, and surface temperature. The dataset also includes all-year daily, warm period daily, 5-day, 10-day and monthly sums for 47 (in total) precipitation gauges within the KWBS territory for different time spans over the period 1948-1997. It also contains soil evaporation data from different landscapes, snow evaporation series from two sites, snow survey results for different watersheds within the KWBS, as well as thaw/freeze depths at more than 30 observational sites.

Based on the observation data, an annual water balance for three micro-watersheds ranging in size from 0.27 to $0.69 \mathrm{~km}^{2}$ was estimated for the whole period of observations. Estimated runoff coefficients varied from 51-56\% at mountain tundra and sparse larch forest to $95 \%$ in rocky talus.

Analysis of flow and meteorological data revealed a general warming trend and increases in precipitation and low flows over the period 1948-1997. Specifically, the increase in annual air temperature amounted to $1.1^{\circ} \mathrm{C}$, annual precipitation has grown by $21 \%$, while annual flow increased by $24 \%$. Positive trends of runoff were also determined in May (92\%), October (166\%), and November (252\%).

The dataset is important because it characterizes the natural settings, which, on the one hand, are nearly ungauged, and on the other hand are representative of the vast mountainous territory of eastern Siberia and north-eastern Russia. It is unique because it combines water balance, hydrological and permafrost data which allow for study of permafrost hydrology interaction processes within the range of all scientific issues, from model development to climate change impact research.

Author contributions. OM and NN digitized and prepared the dataset for publication with assistance from LL and SS. The data were collected in 1948-1997 by the Hydrometeorological Service of the USSR and Russia and published in Observation Reports (1959-1997).

Competing interests. The authors declare that they have no conflict of interest.

Special issue statement. This article is part of the special issue "Hydrometeorological data from mountain and alpine research catchments". It is not associated with a conference.

Acknowledgements. The authors are grateful to two reviewers, Wolf-Dietrich Marchand and Pedro Restrepo, for valuable input. Their comments allowed for better understanding of described data and inspire the continuation of our struggle for the restoration of the Kolyma Water-Balance Station. We also appreciate the help of David Andrew Post for English language correction.

Edited by: Danny Marks

Reviewed by: two anonymous referees

\section{References}

ACIA, Impacts of a Warming Arctic: Arctic Climate Impact Assessment, Cambrige University Press, 2004

Arctic Observatory Network (AON): International Study of Carbon, Water, and Energy Balances in the Terrestrial Arctic, available at: http://aon.iab.uaf.edu, last access: 8 January 2018.

Arp, C. and Stuefer, S. L.: Hydrological and meteorological data from the North Slope of Alaska, University of Alaska Fairbanks, Water and Environmental Research Center, available at: http://ine.uaf.edu/werc/werc-projects/teon/ current-stations/franklin-bluffs/, last access: 17 April 2017.

Alekseev, V. P.: Long-term variability of the spring taryn-aufeises, J. Ice Snow, 56, 73-92, https://doi.org/10.15356/2076-6734-2016$1-73-92,2016$.

Alexeev, V. P., Boyarintsev, Ye. L., Gopchenko, Ye. D., Serbov, N. G., and Zavaliy, N. V.: The mechanism of cryogenic runoff control at the formation of water balance of small mountain rivers in the area of permafrost rocks, Ukrainian Hydrometeorological J., 8, 182-194, 2011 (in Russian).

Bantsekina, T. V.: Dynamics of coarse-grained slope deposits icing during spring thawing, Kolyma J., 2, 28-31, 2001 (in Russian).

Bantsekina, T. V.: Temperature regime and dynamics of icing of coarse-grained slope deposits without filling during spring- 
summer period (case study of the Kontaktovy creek), Kolyma J., 4, 9-1, 2002 (in Russian).

Bantsekina, T. V.: Peculiarities of hydrothermal regime of seasonal thawing layer in coarsely clastic rocks during spring summer period (with an example of Upper Kolyma highland), $\mathrm{PhD}$ thesis, Melnikov Permafrost Institute, Yakutsk, 137 pp., 2003 (in Russian).

Bantsekina, T. V. and Mikhailov, V. M.: To the assessment of the role of intra-soil condensation of water vapor in the formation of the thermal and water regimes of large sediments, Earth's Cryosphere J., 1, 40-45, 2009.

Boyarintsev, E. L.: Estimation of the losses of spring floods in the Upper Kolyma basin, Meteorology, Climatology Hydrology J., 16, 19-24, 1980.

Boyarintsev, E. L.: Azonal factors of rainfall runoff formation in the territory of Kolyma WBS, Proceedings DVNIGMI, 135, 67-93, 1988 (in Russian).

Boyarintsev, E. L. and Gopchenko, E. D.: Summer period water balance of small mountain catchments of the permafrost and its calculation, Meteorology Climatology Hydrology J., 27, 105-116, 1992.

Boyarintsev, E. L. and Nikolaev, S. N.: Groundwater runoff from small watersheds of permafrost zone, in: Materials of scientific, Conf. on the problems of hydrology of the rivers of the BAM zone and the Far East, Gidrometeoizdat, 297-307, 1986 (in Russian).

Boyarintsev, E. L., Gopchenko, E. D., Serbs, N. G., and Legostaev, G. P.: Concerning the condensation of air vapors in the active layer of permafrost M., Dep. in the IC VNIIGMI-WDC 16.01.91, 1046 GM 91, 17, 1991 (in Russian).

Boyarintsev, E. L., Serbov, N. G., and Popova, N. I.: Formation of the water balance of the spring floods of the small mountain watersheds of Upper Kolyma (based on materials from the Kolyma Water-Balance Station), Bulletin of the North-Eastern Scientific Center, Far-Eastern Branch of the Russian Academy of Sciences, 4, 12-19, 2006 (in Russian).

Changing Cold Regions Network project: available at: http://www. ccrnetwork.ca, last access: 8 January 2018.

Chebotarev, N. P.: Flow and hydrological calculations, edited by: Polyakova, B. V. M., Gidrometeoizdat, 294 pp., 1939.

Førland, E. J. (Ed.), Allerup, P., Dahlström, B., Elomaa, E., Jónsson, T., Madsen, H., Perälä, J., Rissanen, P., Vedin, H., and Vejen, F.: Manual for Operational Correction of Nordic Precipitation Data, DNMI-Report 24/96 KLIMA, 66 pp., 1996.

Glotov, V. E.: Ground water of the Kontaktovy Creek watershed as a factor of general drainage system formation, in: Factors affecting the formation of a general drainage system of minor mountain rivers in sub-arctic areas, edited by: Glotov, V. and Ukhov, N., SVKNII DVO RAN, Magadan, 102-141, 2002 (in Russian).

Gorshenin, N. M.: Evaporation of snow in sheltered forest belts and in field interbelt spaces, Meteorology Hydrology J., 4, 80-82, 1948 (in Russian).

Groisman, P. Ya., Bogdanova, E. G., Alexeev, V. A., Cherry, J. E., and Bulygina, O. N.: Impact of snowfall measurement deficiencies on quantification of precipitation and its trends over Northern Eurasia, Ice Snow J., 2, 29-43, 2014.

Gusev, E. M., Nasonova, O. N., and Dzhogan, L. Ya.: The Simulation of Runoff from Small Catchments in the Permafrost Zone by the SWAP Model, Water Resour., 33, 133-145, 2006.
Hobbie, J. E., Shaver, G. R., Laundre, J., Slavik, K., Deegan, L. A., O'Brien, J., Oberbauer, S., and MacIntyre, S.: Climate forcing at the arctic LTER site, in: Climate variability and ecosystem response at long-term ecological research (LTER) sites, edited by: Greenland, D., New York, Oxford University Press, 74-91, 2003.

Hinzman, L. D., Ishikawa, N., Yoshikawa, K., Bolton, W. R., and Petrone, K. C.: Hydrologic Studies in Caribou Poker Creeks Research Watershed in Support of Long term Ecological Research, Eur. J. Forest Res., 5-2, 67-71, 2002.

Improving Processes and Parameterization for Prediction in Cold Regions Hydrology: Centre for Hydrology, University of Saskatchewan, Saskatoon, Saskatchewan, Canada, available at: http://www.usask.ca/hydrology/, last access: 8 January 2018.

Informational letter \#2: 40 years anniversary of the Kolyma Water Balance Station, Kolymskiy Territorial Office on Hydrometeorology, Magadan, 1988 (in Russian).

Janowicz, J. R., Hedstrom, N., Pomeroy, J., Granger, R., and Carey, S.: Wolf Creek Research Basin water balance studies, in: Proceedings of U.S. National Science Foundation/Northern Research Basins, Workshop on Circumpolar Water Balance, Victoria, BC, Canada, 15-19 March 2004.

Kane, D. L. and Hinzman, L.: Upper Kuparuk River, Imnavait Creek, Roche Moutonnee Creek, and Putuligayuk River HydroMeteorologic Datasets, Fairbanks, University of Alaska Fairbanks, Water and Environmental Research Center, 2009.

Kane, D. L. and Yang, D.: Overview of water balance determinations for high latitude watersheds, in: Northern Research Basins Water Balance, King DL, edited by: Yang, D., IAHS publ., 290, 195-204, 2004.

Kedrolivansky, V. N. and Sternzat, M. S.: Meteorological devices, Gidrometeoizdat, Leningrad, 151 pp., 1953 (in Russian).

Kendall, M. G.: Rank Correlation Methods, Griffin, London, 1975.

Konstantinov, A. R.: The evaporation in nature, Gidrometeoizdat, Leningrad, 532 pp., 1968 (in Russian).

Korolev, Yu. B.: Mapping of the vegetation cover in connection with an assessment of its hydrological role (by the example of the Upper Kolyma), $\mathrm{PhD}$ thesis for candidate of biological science, Magadan University, Yakutia, 231 pp., 1984 (in Russian).

Kuchment, L. S., Gelfan, A. N., and Demidov, A. I.: A Model of Runoff Formation on Watersheds in the Permafrost Zone: Case Study of the Upper Kolyma River, Water Resour., 27, 435-444, 2000.

Kuznetsov, A. S., Nasibulin, S. S., and Ipatieva A. I.: The first results of the study of water balance on the rivers of the Upper Kolyma basin, Collection of works of the Magadan Hydrometeorological Observatory, 2, Magadan, 98-121, 1969 (in Russian).

Laudon, H., Spence, C., Buttle, J., Carey, S. K., McDonnell, J. J., McNamara, J. P., Soulsby, C., and Tetzlaff, D.: Saving northern high-latitude catchments, Nat. Geosci., 10, 324-325, https://doi.org/10.1038/ngeo2947, 2017.

Lebedeva, L., Semenova, O., and Vinogradova, T.: Simulation of Active Layer Dynamics, Upper Kolyma, Russia, using the Hydrograph Hydrological Model, Permafrost Periglac. Process., 25, 270-280, https://doi.org/10.1002/ppp.1821, 2014.

Lebedeva, L. S., Semenova, O. M., and Vinogradova, T. A.: Hydrological modeling: seasonal thaw depths in different landscapes of the Kolyma Water Balance Station (Part 2), Earth's Cryosphere J., 2, 35-44, 2015. 
Lebedeva, L. S., Makarieva, O. M., and Vinogradova, T. A.: Spatial variability of the water balance elements in mountain catchments in the North-East Russia (case study of the Kolyma Water Balance Station), Meteorology Hydrology J., 4, 90-101, 2017 (in Russian).

Lilly, E. K., Kane, D. L., Gieck, R. E., and Hinzman, L. D.: Annual water balance for three nested watersheds on the north slope of Alaska, in: Permafrost Proc. seventh Int. Conf., Yellowknife, Canada, 669-674, 1998.

Makarieva, O., Nesterova, N., Lebedeva, L., and Sushansky, S.: Water-balance and hydrology database for a mountainous permafrost watershed in the up-streams of the Kolyma River, Russia - the Kolyma Water-Balance Station, 1948-1997, PANGAEA, https://doi.org/10.1594/PANGAEA.881731, 2017.

Mann, H. B.: Nonparametric tests against trend, Econometrica, 13, 245-259, 1945.

Manual for hydrometeorological stations: Manual for hydrometeorological stations for corrections of observed values of precipitation, Gidrometeoizdat, 30 pp., 1969 (in Russian).

Manual of the water balance stations: anual of the water balance stations, Gidrometeoizdat, 308 pp., 1973 (in Russian).

Mikhaylov, V. M.: Floodplain taliks of North-East of Russia, Novosibirsk, Geo, 244 pp., 2013 (in Russian).

Nasybulin, P. S.: The representativity of runoff characteristics at the Kolyma Water Balance Station for the upper Kolyma area. Natural resources of the USSR North-East, Vladivostok, AN DVIS IBPS, 32-41, 1976 (in Russian).

Northern Research Basins Water Balance: Proceedings of a workshop held at Victoria, Canada, IAHS Publ., 290, 281 pp., 2004.

NPR-A Hydrology, Water and Environmental Research Centre: available at: http://ine.uaf.edu, last access: 8 January 2018.

Observation Reports: Kolyma Water Balance Station, Issues 1-40, 1959-1998, Kolyma UGKS, Magadan, 1948-1997 (in Russian).

Pacific Northwest Natural Areas Network (PNNAN): Fish Creek Research Natural Area, available at: http://www.fsl.orst.edu/rna/ sites/Fish_Creek_Rim.html, last access: 26 September 2014.

Peterson, B. J., Holmes, R. M., McClelland, J. W., Vörösmarty, C. J., Lammers, R. B., Shiklomanov, A. I., Shiklomanov, I. A., and Rahmstorf, S.: Increasing river discharge to the Arctic Ocean, Science, 298, 2171-2173, 2002.

Pietroniro, A., Fortin, V., Kouwen, N., Neal, C., Turcotte, R., Davison, B., Verseghy, D., Soulis, E. D., Caldwell, R., Evora, N., and Pellerin, P.: Development of the MESH modelling system for hydrological ensemble forecasting of the Laurentian Great Lakes at the regional scale, Hydrol. Earth Syst. Sci., 11, 1279-1294, https://doi.org/10.5194/hess-11-1279-2007, 2007.

Pomeroy, J. W., Gray, D. M., Brown, T., Hedstrom, N. R., Quinton, W. L., Granger, R. J., and Carey, S. K.: The cold regions hydrological model: a platform for basing process representation and model structure on physical evidence, Hydrol. Process., 21, 2650-2667, https://doi.org/10.1002/hyp.6787, 2007.

Quinton, W. L., Hayashi, M., and Wright, N.: The Water Balance of Wetland-Dominated Permafrost Basins: A White Paper Submitted to the Water Balance Workshop, in: Proceedings: U.S. National Science Foundation/Northern Research Basins, Workshop on Circumpolar Water Balance, Victoria, BC, Canada, 1519 March 2004, 118-139, 2004.
Reynuk, I. T.: Condensation in active layer of permafrost, Proceedings of All Union Scientific and Research Institute of Gold and Rare Metals, 13, 1-24, 1959.

Semenova, O., Lebedeva, L., and Vinogradov, Yu.: Simulation of subsurface heat and water dynamics, and runoff generation in mountainous permafrost conditions, in the Upper Kolyma River basin, Russia, Hydrogeol. J., 21 107-119, https://doi.org/10.1007/s10040-012-0936-1, 2013.

Sen, P. K.: Estimates of the regression coefficient based on Kendall's tau, J. Am. Stat. Assoc., 63, 1379-1389, 1968.

Shiklomanov, A. I., Lammers, R. B., and Vörösmarty, C. J.: Widespread decline in hydrological monitoring threatens Pan-Arctic Research, Eos Trans. AGU, 83, 13-17, https://doi.org/10.1029/2002EO000007, 2002.

Shmakin, A. B.: The updated version of SPONSOR land surface scheme: PILPS influenced improvements, Global Planet. Change, 19, 49-62, 1998.

Schwer, C. A.: Precipitation at the territory of the USSR, Gidrometeoizdat, 302 pp., 1976 (in Russian).

Slaugher, C. W. and Billelo, M. A.: Kolyma Water Balance Station, Magadan oblast, Northeast U.S.S.R.: United Station - Soviet Scientific Exchange Visit, Special Report 77-155, Army Gold Regions Research and Engineering Laboratory, Hanover, 66 pp., 1977.

Snyder, F., Sokolov, A., and Szesztay, K.: Flood Studies: An International Guide for Collection and Processing of Data, Unesco, Paris, 52 pp., 1971.

St. Jacques, J. M. and Sauchyn, D. J.: Increasing winter baseflow and mean annual streamflow from possible permafrost thawing in the Northwest Territories, Canada, Geophys. Res. Lett., 36, L01401, https://doi.org/10.1029/2008GL035822, 2009.

Sushansky, S. I.: The first interim report of research at KWBS, State Committee of the USSR on Hydrometeorology, Kolyma Department of Hydrometeorology, Magadan, 99 pp., 1988.

Sushansky, S. I.: The second interim report of research at KWBS, State Committee of the USSR on Hydrometeorology, Kolyma Department of Hydrometeorology, Magadan, 114 pp., 1989.

Sushansky, S. I.: The third interim report of research at KWBS, State Committee of the USSR on Hydrometeorology, Kolyma Department of Hydrometeorology, Magadan, 140 pp., 1990a.

Sushansky, S. I.: The final report of research at KWBS, State Committee of the USSR on Hydrometeorology, Kolyma Department of Hydrometeorology, Magadan, 109 pp., 1990b.

Sushansky, S. I.: Peculiarities of water balance elements in the Morozova Creek catchment, Kolyma J., 1, 33-40, 1990c (in Russian).

Sushansky, S. I.: History of creation, methods, objects and some results of studies in the Kolyma water balance station, in: Factors affecting the formation of a general drainage system of minor mountain rivers in sub-arctic areas, edited by: Glotov, V. and Ukhov, N., SVKNII DVO RAN, Magadan, 18-35, 2002.

Tananaev, N. I., Makarieva, O. M., and Lebedeva, L. S.: Trends in annual and extreme flows in the Lena River basin, Northern Eurasia, Geophys. Res. Lett., 43, 10764-10772, https://doi.org/10.1002/2016GL070796, 2016.

Tikhmenev, P. Ye.: Peculiarities of succession process in disturbed lands of the Kolyma river basin, Natural-resources potential, ecology and sustainable development of Russian regions: Col- 
lected works VI International scientific-practical Conf. Penza, PGAU, 273-275, 2008.

Vasilenko, N.: Water balance of small Russian catchments in the southern mountainous Taiga Zone: "Mogot" case study, in: Proceedings U.S. National Science Foundation/Northern Research Basins, Workshop on Circumpolar Water Balance, Victoria, BC, Canada, 15-19 March 2004.

Verseghy, D. L.: CLASS-A Canadian Land Surface Scheme for GCMS: I. Soil Model, Int. J. Climatol., 11, 111-133, 1991.

Vinogradov, Yu. B., Semenova, O. M., and Vinogradova, T. A.: Hydrological modeling: heat dynamics in a soil profile (Part 1), Earth's Cryosphere J., 1, 11-21, 2015.

Walker, D. A. and Walker, M. D.: Terrain and vegetation of the Imnavait Creek Watershed, Landscape Function: Implications for Ecosystem Disturbance, a Case Study in Arctic Tundra, edited by: Reynolds, J. F. and Tenhunen, J. D., Springer-Verlag, New York, NY, 73-108, 1996.

WMO: Instruments and Observing Methods, Report No. 67. WMO Solid Precipitation Measurement Intercomparison, Final Report, WMO/TD-No. 872, 212 pp., 1998.
Yang, D. and Goodison, B. E.: Accuracy of Tretyakov Precipitation gauge: Results of WMO Intercomparison, Hydrol. Process., 9, 877-895, 1995.

Yang, D., Shi, X., and Marsh, P.: Variability and extreme of Mackenzie River daily discharge during 1973-2011, Quaternary Int., 380-381, 159-168, https://doi.org/10.1016/j.quaint.2014.09.023, 2015.

Yarie, J., Viereck, L., Cleve, K., and Adams, P.: Flooding and Ecosystem Dynamics along the Tanana River, BioScience, 48, 690-695, 1998.

Yeh, K.-S., Cote, J., Gravel, S., Methot, A., Patoine, A., Roch, M., and Staniforth, A.: The CMC-MRB global environmental multiscale (GEM) model: Part III - Nonhydrostatic formulation, Mon. Weather Rev., 130, 339-356, 2002.

Yue S., Pilon, P., and Cavadias, G.: Power of the Mann-Kendall and Spearman's rho tests for detecting monotonic trends in hydrological series, J. Hydrol., 259, 254-271, 2002.

Zhuravin, S.: Features of water balance for small mountainous basins in East Siberia: Kolyma Water Balance Station case study, IAHS Publ. 290, IAHS, Wallingford, UK, 28-40, 2004. 